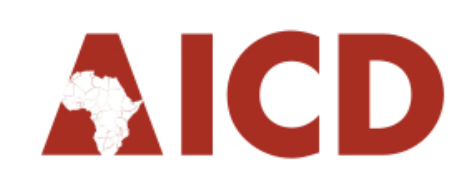

AFRICA INFRASTRUCTURE

COUNTRY DIAGNOSTIC

COUNTRY REPORT

\title{
Cape Verde's Infrastructure: A Continental Perspective
}

Cecilia M. Briceño-Garmendia and Daniel Alberto Benitez 
(C) 2010 The International Bank for Reconstruction and Development / The World Bank

1818 H Street, NW

Washington, DC 20433 USA

Telephone: 202-473-1000

Internet: www.worldbank.org

E-mail: feedback@worldbank.org

All rights reserved

A publication of the World Bank.

The World Bank

1818 H Street, NW

Washington, DC 20433 USA

The findings, interpretations, and conclusions expressed herein are those of the author(s) and do not necessarily reflect the views of the Executive Directors of the International Bank for Reconstruction and Development / The World Bank or the governments they represent.

The World Bank does not guarantee the accuracy of the data included in this work. The boundaries, colors, denominations, and other information shown on any map in this work do not imply any judgment on the part of The World Bank concerning the legal status of any territory or the endorsement or acceptance of such boundaries.

\section{Rights and permissions}

The material in this publication is copyrighted. Copying and/or transmitting portions or all of this work without permission may be a violation of applicable law. The International Bank for Reconstruction and Development / The World Bank encourages dissemination of its work and will normally grant permission to reproduce portions of the work promptly.

For permission to photocopy or reprint any part of this work, please send a request with complete information to the Copyright Clearance Center Inc., 222 Rosewood Drive, Danvers, MA 01923 USA; telephone: 978-750-8400; fax: 978-750-4470; Internet: www.copyright.com.

All other queries on rights and licenses, including subsidiary rights, should be addressed to the Office of the Publisher, The World Bank, 1818 H Street, NW, Washington, DC 20433 USA; fax: 202-522-2422; e-mail: pubrights@worldbank.org. 


\section{AICD \\ angan

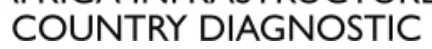

\section{About AICD and its country reports}

This study is a product of the Africa Infrastructure Country Diagnostic (AICD), a project designed to expand the world's knowledge of physical infrastructure in Africa. The AICD provides a baseline against which future improvements in infrastructure services can be measured, making it possible to monitor the results achieved from donor support. It also offers a solid empirical foundation for prioritizing investments and designing policy reforms in Africa's infrastructure sectors.

The AICD is based on an unprecedented effort to collect detailed economic and technical data on African infrastructure. The project has produced a series of original reports on public expenditure, spending needs, and sector performance in each of the main infrastructure sectors, including energy, information and communication technologies, irrigation, transport, and water and sanitation. Africa's Infrastructure-A Time for Transformation, published by the World Bank and the Agence Française de Développement in November 2009, synthesized the most significant findings of those reports.

The focus of the AICD country reports is on benchmarking sector performance and quantifying the main financing and efficiency gaps at the country level. These reports are particularly relevant to national policy makers and development partners working on specific countries.

The AICD was commissioned by the Infrastructure Consortium for Africa following the 2005 G8 (Group of Eight) summit at Gleneagles, Scotland, which flagged the importance of scaling up donor finance for infrastructure in support of Africa's development.

The first phase of the AICD focused on 24 countries that together account for 85 percent of the gross domestic product, population, and infrastructure aid flows of Sub-Saharan Africa. The countries are: Benin, Burkina Faso, Cape Verde, Cameroon, Chad, Côte d'Ivoire, the Democratic Republic of Congo, Ethiopia, Ghana, Kenya, Lesotho, Madagascar, Malawi, Mozambique, Namibia, Niger, Nigeria, Rwanda, Senegal, South Africa, Sudan, Tanzania, Uganda, and Zambia. Under a second phase of the project, coverage was expanded to include as many of the remaining African countries as possible.

Consistent with the genesis of the project, the main focus is on the 48 countries south of the Sahara that face the most severe infrastructure challenges. Some components of the study also cover North African countries so as to provide a broader point of reference. Unless otherwise stated, therefore, the term Africa is used throughout this report as a shorthand for Sub-Saharan Africa.

The World Bank has implemented the AICD with the guidance of a steering committee that represents the African Union, the New Partnership for Africa's Development (NEPAD), Africa's regional economic communities, the African Development Bank (AfDB), the Development Bank of Southern Africa (DBSA), and major infrastructure donors. 
Financing for the AICD is provided by a multidonor trust fund to which the main contributors are the United Kingdom's Department for International Development (DFID), the Public Private Infrastructure Advisory Facility (PPIAF), Agence Française de Développement (AFD), the European Commission, and Germany's Entwicklungsbank (KfW). A group of distinguished peer reviewers from policy-making and academic circles in Africa and beyond reviewed all of the major outputs of the study to ensure the technical quality of the work. The Sub-Saharan Africa Transport Policy Program and the Water and Sanitation Program provided technical support on data collection and analysis pertaining to their respective sectors.

The data underlying AICD's reports, as well as the reports themselves, are available to the public through an interactive Web site, www.infrastructureafrica.org, that allows users to download customized data reports and perform various simulations. Many AICD outputs will appear in the World Bank's Policy Research Working Papers series.

Inquiries concerning the availability of data sets should be directed to the volume editors at the World Bank in Washington, DC.

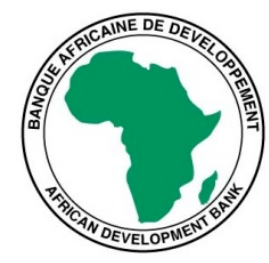

DFID

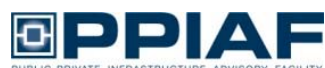

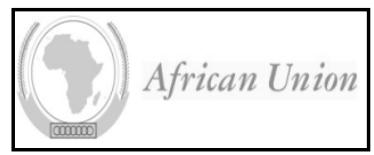
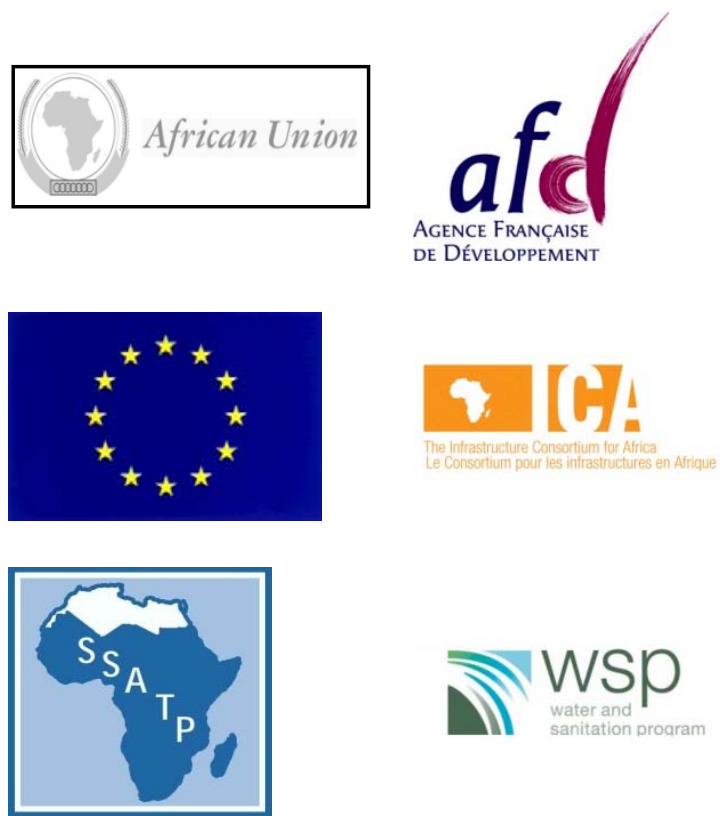
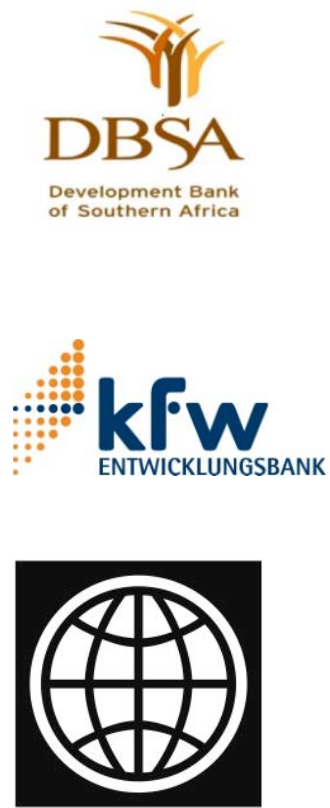


\section{Contents}

$\begin{array}{lr}\text { Synopsis } & 1\end{array}$

The continental perspective $\quad 2$

Why infrastructure matters $\quad 2$

The state of Cape Verde's infrastructure $\quad 3$

Roads

Ports

Air transport

Power

Water supply and sanitation

Information and communications technologies

Financing Cape Verde's infrastructure

How much does Cape Verde spend on infrastructure?

How much more can be done within the existing resource envelope?

7

8

10

14

17

20

20

22

References and bibliography

\section{Acknowledgments}

This paper draws upon a wide range of contributions from sector specialists on the AICD Team: notably, Dick Bullock on railways, Mike Mundy on ports, Heinrich Bofinger on air transport, Maria Shkaratan on power, Elvira Morella on water and sanitation, Michael Minges on information and communication technologies, Nataliya Pushak on public expenditure, and Alvaro Federico Barra on spatial analysis.

The paper is based on data collected by local consultants, and benefited greatly from feedback provided by colleagues in the relevant World Bank country teams; notably Habib Fetini (country director), Manuela Francisco (country economist), and Kavita Sethi (transport). 


\section{Synopsis}

Across West Africa, infrastructure improvements - most notably in the information and communications technology (ICT) sector-have contributed some 0.9 percentage points to recent improvements in per capita growth rates. Looking ahead, if West Africa's infrastructure performance could be enhanced to the levels of Africa's leading country, Mauritius, growth performance could be boosted by 2.9 percentage points per capita.

Within Africa, Cape Verde stands out as a country whose economic geography poses major and unique challenges to infrastructure development. Cape Verde's small population, comprising some half a million people, is spread across the nine islands that form the archipelago, many of them sparsely populated. This means that in addition to maintaining multiple road networks, the country needs a large number of functioning ports to assure internal connectivity, and also relies heavily on air transport for both domestic and international links. A lack of domestic energy resources leaves the country dependent on imported diesel fuel for power generation, while the small scale of the market makes the cost of both importing fuel and generating electricity exceptionally high. Marked water scarcity makes Cape Verde rely on desalination to meet 85 percent of its human water needs, and this energy-intensive process is made even more prohibitive by the high cost of power. Being at a significant distance of 500 kilometers $(\mathrm{km})$ from the African coast means that Cape Verde must finance a significant spur from the regional submarine cable to ensure its access to broadband technology.

As befits its middle-income status, Cape Verde already has quite well-developed infrastructure networks. Road density is relatively high, and around three-quarters of the national network is paved to some degree. Almost all of the nine islands have port and airport facilities. Around 70 percent of the population has access to power and (some form of) utility water. The country has access to a submarine cable, and indicators for ICT coverage — penetration and bandwidth—are relatively good.

Nevertheless, prices of all services are exceptionally high, reflecting the high-cost environment described above. Power prices, at over $\$ 0.40$ per kilowatt-hour $(\mathrm{kWh})$, and water tariffs, at $\$ 4.43$ per cubic meter $\left(\mathrm{m}^{3}\right)$, are by far the highest in Africa and must be among the highest in the world; yet, even so, cost recovery is inadequate. High prices have led to relatively low usage of infrastructure services: both power and water consumption are a fraction of middle-income levels. Prices of ICT services are also around 50 percent higher than regional benchmarks.

In addition to high prices, the quality of services is often deficient. At least half of the national road network is in poor condition. The power sector has been plagued by unreliable supply. Around half of the population receiving utility water depends on standposts rather than private taps. There are also serious operational inefficiencies, including relatively high distribution losses for both power and water.

On the institutional side, Cape Verde has been relatively open to private participation. A controlling share of the national power and water multiutility, ELECTRA, was sold to the private sector (though its stake was subsequently reduced to a minority one). Two licenses have been awarded for mobile telephony services, and the inter-island ferry service has been privatized. The government has also been considering private sector participation in the ports and aviation sector, although nothing has been decided as yet. 
Cape Verde devotes around $\$ 147$ million per year-or almost 15 percent of gross domestic product (GDP) - to infrastructure, one of the highest levels of infrastructure spending found on the African continent. Spending is quite heavily skewed toward capital expenditure, and the resources devoted to transport are particularly high relative to regional benchmarks. In addition, some $\$ 50$ million a year is being lost to inefficiencies of various kinds, primarily underpricing and operational inefficiencies in the power sector.

In sum, the main challenges for the country are to improve the effectiveness with which resources are being used, and to seek new approaches to reducing the exceptionally high costs of infrastructure service provision.

\section{The continental perspective}

The Africa Infrastructure Country Diagnostic (AICD) has gathered and analyzed extensive data on infrastructure in more than 40 Sub-Saharan countries, including Cape Verde. The results have been presented in reports covering several sectors-ICT, irrigation, power, transport, water and sanitationand various policy areas, including investment needs, fiscal costs, and sector performance.

This report presents the key AICD findings for Cape Verde, allowing the country's infrastructure situation to be benchmarked against that of its African peers. Given that Cape Verde is a relatively welloff middle-income country, its performance will be benchmarked against that of other middle-income countries in Africa. Detailed comparisons will also be made with immediate regional neighbors in the Economic Community of West African States (ECOWAS), and where relevant, with other island states that face a similar set of infrastructure challenges

Several methodological issues should be borne in mind. First, because of the cross-country nature of data collection, a time lag is inevitable. The period covered by the AICD runs from 2001 to 2006, yet most technical data presented are for 2006 (or the most recent year available), while financial data are typically averaged over the available period to smooth out the effect of short-term fluctuations. Where possible, data have been collected for the period 2007 to 2009 to measure the progress made relative to the baseline. Second, to make comparisons across countries, we had to standardize the indicators and analysis; hence some of the indicators presented here may be slightly different from those that are routinely reported and discussed at the country level.

\section{Why infrastructure matters}

Alongside the rest of the continent, West Africa's growth performance improved markedly between the 1990s and 2000s. The overall improvement in per capita growth rates has been estimated at close to 2 percentage points, of which 1.1 percent is attributable to better structural policies and 0.9 percent to improved infrastructure. Although specific estimates are not available for Cape Verde, the experience of neighboring West African states suggests that the net per capita growth impact of infrastructure during this period ranged from 1.6 percentage points in Benin to 0.1 percentage points in Guinea-Bissau 
(figure 1a). While the overall impact of infrastructure on growth was positive, in a number of countries deficient power infrastructure acted as a significant break on growth, as did inadequate road infrastructure in a few cases.

Figure 1. Infrastructure has contributed much to economic growth-but could contribute much more

a. Infrastructure's contribution to annual per capita economic growth in selected countries, 2003-07, in percentage points

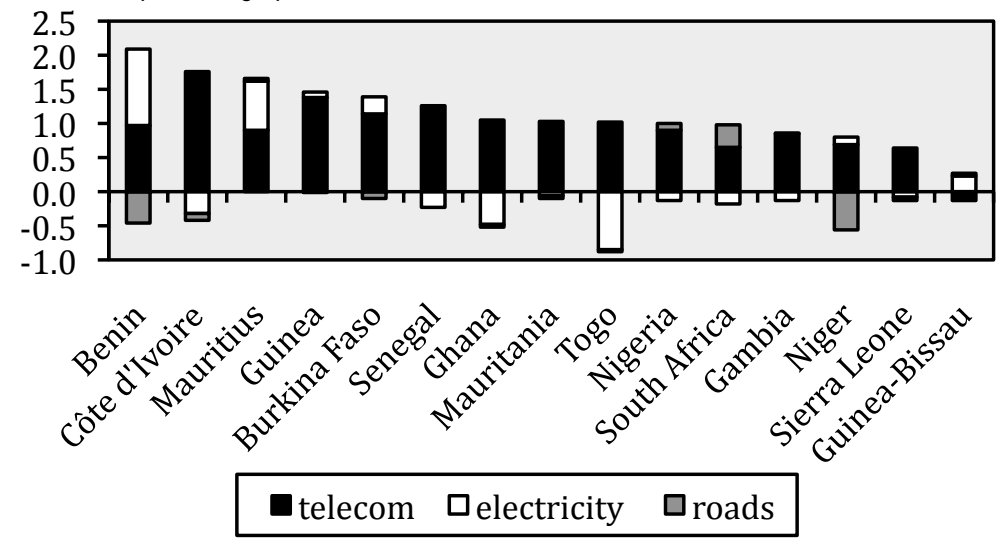

b. Potential contributions of infrastructure to annual per capita economic growth in selected countries, in percentage points

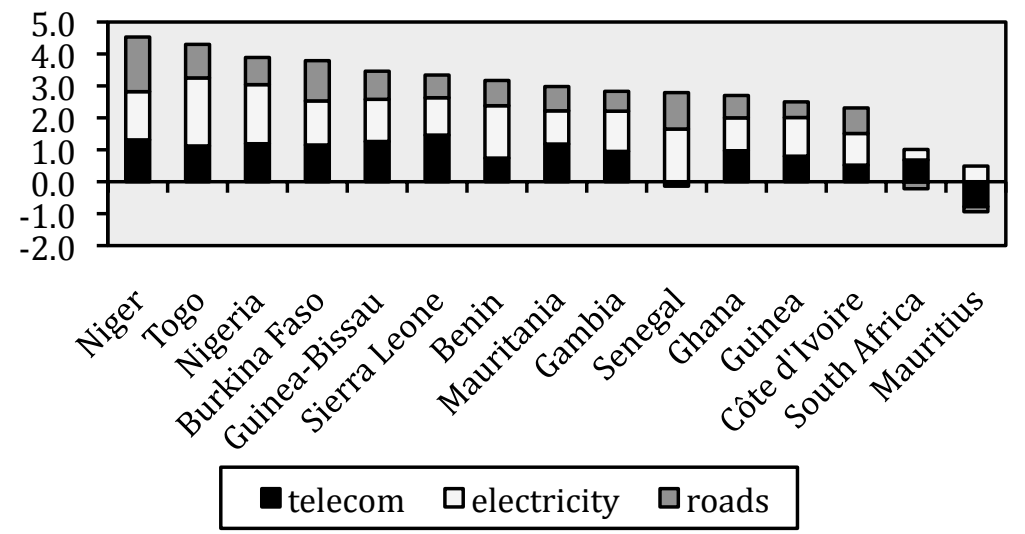

Source: Calderón 2009.

Looking ahead, simulations suggest that if the countries of West Africa were able to improve their infrastructure to the level of the African leader-Mauritius-annual per capita growth rates would be 2.9 percentage points higher, on average, than they are at present. This impact would come mainly from improvements across the three main infrastructure sectors (roads, electricity, and telecommunications; see figure 1b). Overall, evidence from enterprise surveys suggests that infrastructure constraints are responsible for about 40 percent of the productivity handicap faced by African firms.

\section{The state of Cape Verde's infrastructure}

Cape Verde's geography has contributed to the nation's relatively high cost of infrastructure services and access limitations. A population of approximately half a million is dispersed across a nine-island 
archipelago located 500 kilometers $(\mathrm{km})$ off the West African coastline. Geographical fragmentation and a low population density necessitate the duplication of infrastructure facilities. For example, despite its small population Cape Verde has no fewer than three international airports, four aerodromes, and nine ports. The decentralized and very fragmented provision of utility services prevents capture of scale economies and drives up the cost and price of services, making it difficult to choose appropriate technologies.

Figure 2. Population density

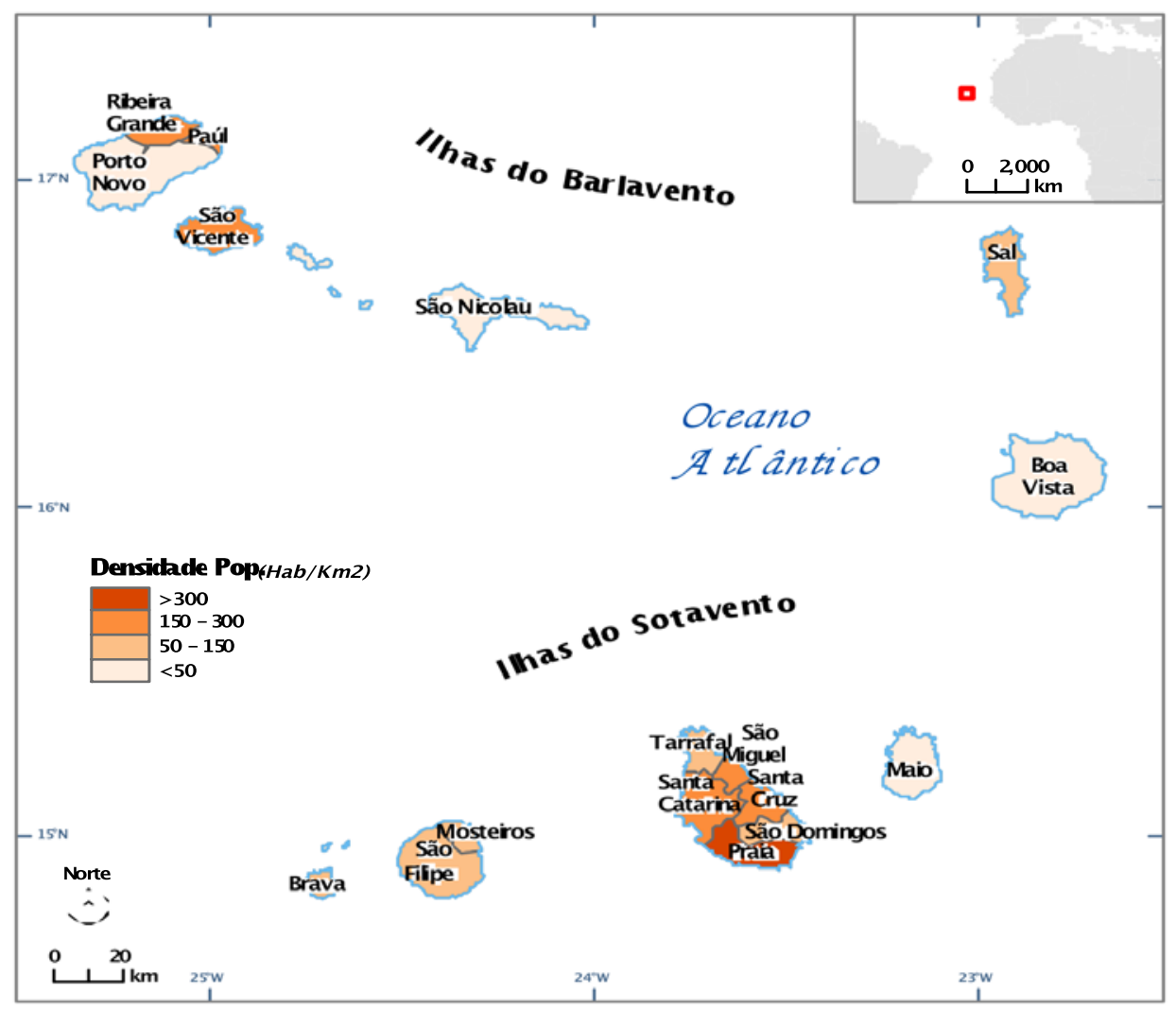

Source: Plano Estratégico de Transportes-Strategic Transport Plan of Cape Verde.

The country has no known oil resources, and water is extremely scarce. Cape Verde is entirely reliant on oil imports for its fuel supply, and the relatively small scale of its market contributes to the high price of this oil. With regard to water resources, Cape Verde has the lowest endowment of any Sub-Saharan African country except for Djibouti in the semi-arid Sahel region. Indeed, over the past 40 years rainfall has decreased sharply, to about half its former level. Underground resources are very limited, and only the islands of Santo Antão and Fogo have any significant water source. As a result, Cape Verde increasingly relies on desalination plants for water, which now account for approximately 85 percent of production.

Cape Verde's isolated geography also limits the extent of its regional integration. Transport connections take the form of air and sea links. As of 2007 Dakar Senegal was acting as the main gateway for air transport service to Cape Verde, hosting daily flights. The country is already connected to the 
Atlantis 2 cable, and plans to connect to a second cable, the WACS (West African Cable System), in 2011.

This report will now review the main achievements and challenges observed in Cape Verde's major infrastructure sectors (see table 1 for a summary of key findings). It will then turn to the problem of how to finance Cape Verde's outstanding infrastructure needs.

Table 1. Achievements and challenges in Cape Verde's infrastructure sectors

\begin{tabular}{|c|c|c|}
\hline & Achievements & Challenges \\
\hline Air transport & $\begin{array}{l}\text { Well-functioning network of airports } \\
\text { Attained international security standards }\end{array}$ & Continuing subsidies to TACV \\
\hline ICT & $\begin{array}{l}\text { Market liberalization completed } \\
\text { Rapid growth in coverage and penetration } \\
\text { Access to submarine cable }\end{array}$ & Reducing prices through enhanced competition \\
\hline Ports & Well-functioning network of ports & $\begin{array}{l}\text { Completing institutional reform agenda } \\
\text { Expanding capacity }\end{array}$ \\
\hline Power & High rates of electrification & $\begin{array}{l}\text { Maintaining tariffs at cost-recovery levels } \\
\text { Reducing cost of power generation } \\
\text { Improving efficiency of ELECTRA }\end{array}$ \\
\hline Roads & $\begin{array}{l}\text { High-density road network Establishment } \\
\text { of road fund }\end{array}$ & $\begin{array}{l}\text { Improving road network conditions } \\
\text { Securing adequate funds for maintenance } \\
\text { Clarifying roles of sector institutions }\end{array}$ \\
\hline Water and sanitation & Good rates of access to utility water & $\begin{array}{l}\text { Improving efficiency of ELECTRA } \\
\text { Raising access to improved sanitation }\end{array}$ \\
\hline
\end{tabular}

Source: Authors' elaboration, based on findings of this report.

Note: ICT = information and communications technology; TACV = Cabo Verde Airlines.

\section{Roads}

\section{Achievements}

Compared with similar countries, Cape Verde has a dense road network. Cape Verde's main national network amounts to a little over $1,000 \mathrm{~km}$, increasing to $1,600 \mathrm{~km}$ when urban and other unclassified roads are taken into account. There are only three islands with road networks in excess of $100 \mathrm{~km}$ : Santiago, Santo Antão, and Fogo. Nevertheless, given the small size of the country, road density (measured as a percentage of arable land) ${ }^{1}$ is 3.5 in Cape Verde, higher than the comparator countries (for instance, Maldives, 2.2; Mauritius, 2.0; Indonesia, 1.6). This dense road network allows the entire population access to health, education, and other basic services. It also serves to interconnect the domestic market.

Almost three-quarters of the national road network is paved. The rest of the network divides evenly between gravel and earth roads. The extent of paving varies significantly across islands, from 100 percent paved in San Nicolau and San Vicente to little more than 50 percent paved in Santiago. Cape Verde uses a

\footnotetext{
${ }^{1}$ According to the World Bank Indicators, in 2003 the total land in Cape Verde was equal to 4,033 square kilometers $\left(\mathrm{km}^{2}\right)$, of which 11.4 percent was considered arable land $\left(460.3 \mathrm{~km}^{2}\right)$. Thus, road density is the ratio of road length to arable land (in $\mathrm{km}^{2}$ ): $1,607 \mathrm{~km} / 460.3 \mathrm{~km}^{2}=3.5$.
} 
variety of different paving technologies (mainly calçada de paralelos, and calçada Portuguesa-a local form of cobblestone); most of its paved roads are not conventional asphalt roads.

Table 2. Cape Verde's road network, 2005

\begin{tabular}{|c|c|c|c|c|c|c|c|}
\hline & \multirow{2}{*}{$\begin{array}{l}\text { Total length } \\
\quad(\mathrm{kms})\end{array}$} & \multicolumn{3}{|c|}{ Condition (\%) } & \multicolumn{3}{|c|}{ Surface (\%) } \\
\hline & & Good & Fair & Poor & Paved $^{*}$ & Gravel & Earth \\
\hline National & 1,002 & 25.0 & 23.1 & 52.0 & 73.7 & 12.4 & 14.0 \\
\hline Santiago & 364 & 16.8 & 8.7 & 74.5 & 55.6 & 6.1 & 38.3 \\
\hline Santo Antao & 196 & 47.6 & 31.0 & 21.4 & 97.6 & 2.4 & 0.0 \\
\hline Fogo & 169 & 40.0 & 16.8 & 43.2 & 72.6 & 14.7 & 12.6 \\
\hline S. Nicolau & 95 & 63.4 & 36.6 & 0.0 & 100.0 & 0.0 & 0.0 \\
\hline Maio & 48 & 13.3 & 6.7 & 80.0 & 76.7 & 16.7 & 6.7 \\
\hline S. Vicente & 42 & 43.8 & 25.0 & 31.3 & 100.0 & 0.0 & 0.0 \\
\hline Sal & 41 & 25.8 & 28.8 & 45.3 & 70.9 & 17.3 & 11.8 \\
\hline Boavista & 30 & 8.3 & 28.4 & 63.3 & 78.1 & 17.2 & 4.7 \\
\hline Brava & 17 & 0.0 & 17.6 & 82.4 & 100.0 & 0.0 & 0.0 \\
\hline Others & 605 & 10.4 & 19.5 & 70.1 & 23.8 & 29.4 & 46.8 \\
\hline Total & 1,607 & 19.5 & 21.7 & 58.8 & 54.9 & 18.8 & 26.3 \\
\hline
\end{tabular}

Source: Instituto da Estrada-Roads Agency of Cape Verde.

Note: * Paved roads cover a number of technologies, including betao bituminso, bicouche, calçada de paralelos, and calçada Portuguesa (some of which are local forms of cobblestone). Few paved roads are conventional asphalt roads.

\section{Challenges}

At least half of the national network is in poor condition, according to data reported by the national road institute for the mid-2000s. A more recent, 2008 transport strategy document suggests that this share may have risen to nearly 70 percent. The quality of the network varies considerably across the country. For instance, while the network in San Nicolau appears to be almost entirely in good or fair condition, about three-quarters of the network in Santiago is reported to be in poor condition. Overall, the situation suggests that Cape Verde's policy of extending the network to low-density areas, in which economic returns are low, may have raised maintenance costs to an unsustainable level, or that this maintenance may not have been planned or accounted for.

Despite the establishment of a road maintenance fund, securing adequate funds for network preservation has proved to be $a$ challenge. A new road maintenance fund became operational in 2006 , implemented by a mechanism that transfers the taxation proceeds from the point of collection directly to the fund for use by the road institute. The accounts of the fund are public, and accountability ensured. The fund is maintained at a minimum—guaranteed by the Treasury—of CVE 300 million, or just under $\$ 4$ million. In 2006 customs transferred taxes to the road maintenance fund, while in 2007 and 2008 the fund was subsidized by the Treasury, albeit at a level below the guaranteed rate. In 2009 the Council of Ministers approved a fuel levy of CVE 7 per liter, equivalent to around $\$ 0.09$. This is a mid-range levy when compared to others observed in Sub-Saharan Africa.

The road agency has tended to overreach its maintenance role by managing the construction of new roads. The mandate of the road agency is to maintain the national road network. The government legislated that public works should always be procured, coordinated, and supervised by the line ministry. 
Thus, the road agency has no formal capacity or experience in procuring, coordinating, or supervising road investments. Despite this fact, in 2007 it was managing the construction of new roads. The road agency needs to expand its technical staff to serve effectively in this role.

\section{Ports}

\section{Achievements}

Maritime transportation is of great importance in Cape Verde, given that the country is an archipelago. All the islands have ports that allow maritime access: nine in total, of which three (Praia, Porto Grande, and Porto da Palmeira) receive international traffic. The ports of Fogo, Brava, and Santo Antão are very small, which limits the types of vessels traveling to these islands. Of the three international ports, only Porto Grande and Praia have the capacity to receive large ships and move and store containers. Overall traffic increased significantly from 2004 to 2006, as container traffic grew at an average annual rate of 20 percent and general cargo traffic at 10 percent.

\section{Challenges}

Cape Verde has been considering a transition from the service to landlord port model. All ports are state owned and managed by the state port authority, ENAPOR, under the service port concept. The government decided long ago to privatize the ENAPOR management, but the process has met many obstacles. The government's reform plans include the adoption of legislation to create a port administration (superseding ENAPOR) that would operate under a landlord model, regulating port operations while frontline port activities at all national ports would be delegated to the private sector via management or concession contracts.

The expansion of port capacity in Cape Verde is a priority. At Mindelo there is a plan to expand port capacity to meet an anticipated increase in transshipment activity. Plans are at an outline stage, but the project appears to be gathering momentum. In Praia nearly half of the $\$ 117$ million allocated to Cape Verde under the Millennium Challenge Account has been invested in a major upgrade of the port. The port will be divided into two maritime areas: Santa Maria and Santo Antão, the former comprising facilities to provide passenger-related shipping services — cruise, roll on-roll off, and catamarans—and the latter, new facilities for cargo operations.

The main inter-island ferry service has already been privatized, and a subsidy ensures minimum service on low-demand routes. Even if not profitable, such connections are important to interconnect the domestic market and also from a social point of view. That said, both local inhabitants and tourists have criticized ships that combine passengers and cargo for running late.

Port performance leaves something to be desired. Benchmarking the performance of Cape Verde's largest port, Porto Grande at Mindelo, against other West African ports illustrates the relatively small size of the country's port operations. While service charges are reasonable by West African standards, the level of port performance does not compare very favorably. For example, the average container dwell time is 16 days at Mindelo compared with 7 days in Dakar, while the vessel pre-berth waiting time is 24 hours in Mindelo compared with less than 3 hours in Abidjan. 
Table 3. Benchmarking port indicators: Porto Grande of Mindelo as compared with other West African ports

\begin{tabular}{|c|c|c|c|c|c|c|c|c|}
\hline & 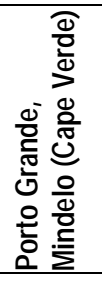 & 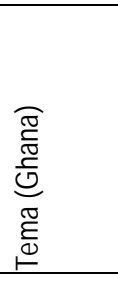 & 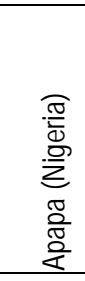 & 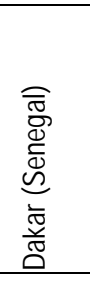 & 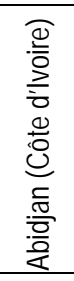 & $\begin{array}{l}\widetilde{\bar{D}} \\
\overline{\bar{D}} \\
\varrho \\
\bar{\Xi} \\
\overline{0} \\
\overline{0} \\
\stackrel{0}{0} \\
\end{array}$ & 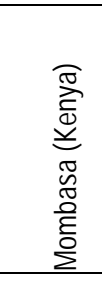 & 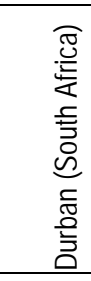 \\
\hline \multicolumn{9}{|l|}{ Capacity } \\
\hline $\begin{array}{l}\text { Actual containers handled } \\
\text { ('000sTEU/year) }\end{array}$ & 170 & 471 & 336 & 306 & 500 & 158 & 437 & 1,899 \\
\hline $\begin{array}{l}\text { Actual general cargo handled ('000s } \\
\text { tonnes/year) }\end{array}$ & 699 & 7,900 & 3,400 & 6,109 & n.a. & 1,100 & 12,980 & 16,100 \\
\hline $\begin{array}{l}\text { General-cargo-handling capacity ('000s } \\
\text { tonnes/year) }\end{array}$ & 800 & 8,500 & 5,000 & n.a. & n.a. & 2,500 & 1,500 & n.a. \\
\hline \multicolumn{9}{|l|}{ Efficiency } \\
\hline $\begin{array}{l}\text { Average container dwell time in terminal } \\
\text { (days) }\end{array}$ & 16 & 25 & 42 & 7 & 12 & 12 & 5 & 4 \\
\hline $\begin{array}{l}\text { Average truck-processing time for receipt } \\
\text { and delivery of cargo (hours) }\end{array}$ & 6 & 8 & 6 & 5 & 2.5 & 6 & 4.5 & 5 \\
\hline $\begin{array}{l}\text { General-cargo vessel preberth waiting } \\
\text { time (hours) }\end{array}$ & 24 & 9.6 & n.a. & 24 & 2.9 & 48 & 36 & n.a. \\
\hline $\begin{array}{l}\text { General-cargo vessel turnaround time } \\
\text { (hours) }\end{array}$ & 36 & 48 & n.a. & 60 & 2.2 & 48 & 48 & n.a. \\
\hline $\begin{array}{l}\text { Average container crane productivity } \\
\text { (containers loaded/unloaded per crane } \\
\text { hour) }\end{array}$ & n.a. & 13 & 12 & n.a. & 18 & & 10 & 15 \\
\hline $\begin{array}{l}\text { Average general-cargo crane productivity } \\
\text { (tonnes loaded/unloaded per crane } \\
\text { working hour) }\end{array}$ & 6 & 13.5 & 9 & n.a. & 16 & 15 & 20.8 & 25 \\
\hline \multicolumn{9}{|l|}{ Tariffs } \\
\hline $\begin{array}{l}\text { Average container-handling charge, ship } \\
\text { to gate }(\$ / T E U)\end{array}$ & 100 & 168 & 155 & 160 & 260 & 180 & 67.5 & 258 \\
\hline $\begin{array}{l}\text { Average general-cargo-handling charge, } \\
\text { ship to gate (\$/tonne) }\end{array}$ & 10.0 & 10.0 & 8.0 & 15.0 & 13.5 & 8.5 & 6.5 & 8.4 \\
\hline $\begin{array}{l}\text { Average dry-bulk-handling charge, ship } \\
\text { to gate or rail }(\$ / \text { tonne) }\end{array}$ & 5.0 & 3.0 & n.a. & 5.0 & 5.0 & 5.0 & 5.0 & 1.4 \\
\hline $\begin{array}{l}\text { Average liquid-bulk-handling charge, ship } \\
\text { to gate or rail (\$/tonne) }\end{array}$ & 2.5 & 1.5 & 1.0 & 4.0 & n.a. & n.a. & n.a. & n.a. \\
\hline
\end{tabular}

Source: Ocean Shipping Consultants 2009. Derived from the AICD ports database (http://www.infrastructureafrica.org/aicd/tools/data).

Note: TEU $=20$-foot equivalent units.

n.a. $=$ Not applicable.

\section{Air transport}

\section{Achievements}

Given Cape Verde's isolation and growing tourism industry, air transport plays an important role in the economy. Cape Verde now has four international airports (Sal, Praia, Boa Vista, and São Vicente) as well as three additional aerodromes. The international airports, including their buildings, facilities, and runways, have been recently renovated. The remaining three (Fogo, Maio, and Sao Nicolau) serve 
domestic traffic only. Sal and Praia are the only 24-hour operational airports, with about half of the traffic concentrated at Sal. Sal was long used by South African Airlines as a transit stop for North American flights, but these flights have since been rerouted to Accra and Dakar. The booming tourism industry has ensured the entrance of new airlines (scheduled and charter) into the market. Air traffic grew at a modest average annual rate of 2.5 percent in 2001-06, while connectivity (as measured by the number of city pairs served) has increased significantly.

Cape Verde's domestic air transport market looks large relative to its West African neighbors due to the use of air travel to interconnect the archipelago; while its international air transport market looks quite small. Nevertheless, relative to its small population, Cape Verde makes very intensive use of air transport; 2.4 seats are available per capita, compared to 0.2 seats in Senegal. The limited size of the market means that there is a high degree of concentration: Cape Verde has the highest Herfindahl index of the comparator countries. ${ }^{2}$

From a safety perspective, Cape Verde performs well. It is one of a handful of African countries that have passed an audit by the Federal Aviation Administration/ International Aviation Safety Association (FAA/IASA), with both Sal and Praia satisfying Category I requirements. This safety certification for both air traffic control and airport operations requires costly investments in facilities and training. In addition, the fleet is almost entirely made up of new aircraft. The flag carrier Cabo Verde Airlines (TACV) enjoys the International Air Transport Association's (IATA's) Operational Safety Audit (IOSA) certification, and offers direct flights to the United States as well as to Europe.

Airports are managed by a state-owned enterprise, Empresa Nacional de Aeroportos e Segurança Aérea (ASA). The company is corporatized and has followed standard business procedures since 2001. Activities include the support of civil aviation; air traffic management; services related to the departure, arrival, and overflight of aircraft; and management of terminals and freight couriers. Due to Cape Verde's strategic location in the Atlantic, the Flight Information Region and associated flight information and alerting services represent the main source of company revenue.

\section{Challenges}

The national carrier remains state owned and absorbs significant government subsidies. Air transport, domestic and international, is offered by TACV with a fleet of five aircraft. Even though the government decided to privatize the company several years ago, the process has been lengthy and inconclusive, and TACV remains state owned. According to government analysis, international flights break even and interisland flights are not profitable. Though TACV expanded seat capacity by more than 10 percent annually over the period 2001-06, traffic growth did not keep pace, resulting in declining aircraft load factors. As a result, the government has systematically channeled significant financial and human resources to the aeronautical sector. Indeed, spending on air transport (mainly on TACV) absorbs approximately 40 percent of total infrastructure spending (or 11 percent of GDP); almost all of these resources are allocated to operations and maintenance (O\&M).

\footnotetext{
${ }^{2}$ The Herfindahl index, a measure of market concentration, is computed by summing the squares of the market share of each market participant.
} 
Despite high levels of safety, TACV suffers from operational management problems that tend to undermine the reliability of scheduling and baggage-handling services. The entry of a new operator competing with TACV on West African routes would serve to create pressure for service improvements.

Table 4. Benchmarking air transport indicators for Cape Verde and selected West African countries

\begin{tabular}{|c|c|c|c|c|c|c|}
\hline Country & $\begin{array}{l}\text { Cape } \\
\text { Verde }\end{array}$ & Ghana & $\begin{array}{c}\text { Côte } \\
\text { d'Ivoire }\end{array}$ & Senegal & Kenya & Tanzania \\
\hline \multicolumn{7}{|l|}{ Traffic (2007) } \\
\hline Domestic seats (millions per year) & 0.58 & 0.14 & 0 & 0.13 & 2.09 & 1.87 \\
\hline Seats for international travel within Africa (millions per year) & 0.54 & 0.91 & 0.85 & 1.26 & 3.14 & 1.27 \\
\hline Seats for intercontinental travel (millions per year) & 0.06 & 0.83 & 0.30 & 1.23 & 2.76 & 0.59 \\
\hline Seats available per capita & 2.40 & 0.08 & 0.06 & 0.23 & 0.28 & 0.12 \\
\hline Herfindahl index-domestic market (\%) & 100.0 & 100.0 & - & 100.0 & 60.5 & 31.0 \\
\hline Herfindahl index-international market (\%) & 42.0 & 6.4 & 9.8 & 10.3 & 34.1 & 13.0 \\
\hline \multicolumn{7}{|l|}{ Quality } \\
\hline Percent of seat $\mathrm{km}$ in medium or smaller aircraft & 93.6 & 15.7 & 52.3 & 39.3 & 23.3 & 48.6 \\
\hline Percent of seat km in newer aircraft & 99.1 & 96.8 & 90.8 & 98.3 & 80.2 & 79.3 \\
\hline Registered carriers on EU blacklist & 0 & 0 & 0 & 0 & 0 & 0 \\
\hline FAA/IASA audit status & Pass & Fail & Fail & No audit & No audit & No audit \\
\hline Percent of carriers passing IATA/IOSA audit & 50.0 & 0 & 0 & 50.0 & 11.1 & 33.3 \\
\hline
\end{tabular}

Source: Bofinger 2009. Derived from the AICD national database (http://www.infrastructureafrica.org/aicd/tools/data).

Note: EU = European Union; FAA = Federal Aviation Administration; IASA = International Aviation Safety Association; IATA = International Air Transport Association; IOSA = IATA Operational Safety Audit.

\section{Power}

\section{Achievements}

Cape Verde has achieved a relatively high rate of electrification that - at 66 percent of the population-compares favorably with other middle-income countries in Sub-Saharan Africa (table 5). This outcome reflects a strong political commitment to provide basic services to the entire population.

The national power and water utility has a minority private sector stake. Power is supplied by the multi-utility ELECTRA, which is also responsible for water supply on at least some of the islands. In 1999 ELECTRA became a public-private partnership through the sale of 51 percent of the share value of the production assets of electricity and water. The government retained 34 percent of the share value, and the municipalities retained 15 percent. As a result of a series of failed negotiations between the private stakeholders and the government, the state regained the position of major shareholder (51 percent) in May 2008. Private stakeholders retained 34 percent, and the municipalities retained 15 percent. 


\section{Challenges}

Blackouts became more frequent during the mid-2000s due to a tight demand-supply balance. Between 2002 and 2006, installed capacity decreased approximately 4.4 percent, while connections rose by 40 percent and production by 10 percent. As a result of the tight demand-supply balance, the incidence of blackouts more than tripled and became longer in duration. According to the Investment Climate Survey (2006), firms in Cape Verde perceive the poor performance of the power sector as the greatest constraint on their operations and growth. Over 60 percent of the firms surveyed see the condition of the power sector as a major or very severe obstacle to their business.

ELECTRA's operational performance is not all that impressive. It certainly falls well short of the African middle-income-country benchmarks for utility performance. In fact, on aspects such as collection efficiency, distribution losses, and cost recovery, ELECTRA's performance was very close to the African low-income-country benchmark for 2006 (table 5). While the collection ratio improved gradually during the period 2006-09, system losses deteriorated substantially, reaching 26 percent by 2009 (table 6). These operational inefficiencies led to substantial hidden costs for the sector, amounting to over 1 percent of GDP by 2009 (figure 5).

Cape Verde's power prices are among the most expensive in Africa (figure 3). Energy production is largely dependent on diesel plants, which in turn rely on expensive fuel imports. A single power price is applied across all the islands despite differences in costs-a geographical cross-subsidization that is justified on the grounds of social equity. Due to the small size of the system, the decision of a single large customer (such as a hotel) to self-supply can substantially increase the costs of power across the system as it reduces scale economies. The authorities are planning to replace diesel-fired generating plants with plants that use fuel oil, which would immediately halve the costs of fuel. The government also plans to invest in renewable energy to improve technical efficiency and reduce oil dependency.

\section{Figure 3. Comparison of electricity tariffs across Africa}

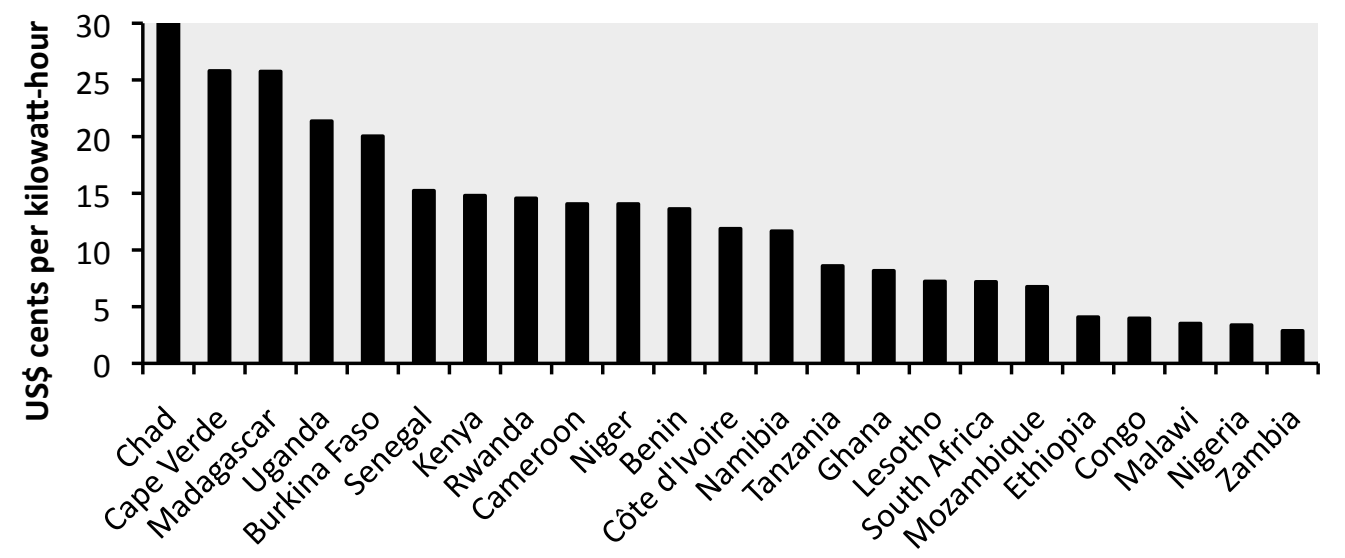

Source: Derived from Eberhard and others (2008).

Although power prices are relatively high, they have nonetheless failed to recover the full economic costs of production. Inadequate tariff setting has long been a critical issue, exacerbated by burgeoning oil prices. Given that fuel costs represent 70 percent of power production costs, a lack of adjustment in response to rising oil prices in the mid-2000s resulted in financial deterioration and depletion of the 
company's capital (figure 4). In 2000 it was agreed that both power and water tariffs would be adjusted once fuel prices exceeded a threshold value of $\$ 0.42$ per liter. These adjustments failed to take place. Instead, the state compensated for rising fuel prices with a direct subsidy that, as of 2005, amounted to \$4.4 million annually. In April 2006 the authorities eliminated this oil subsidy and implemented a series of tariff hikes that failed to fully compensate for further increases in the price of oil. Thereafter, the regulatory agency introduced an automatic adjustment mechanism for electricity and water tariffs linked to the price of petroleum, although none of these mechanisms is being applied as stated by law. While the measures taken in the mid-2000s served to stem the hidden costs associated with underpricing in the sector, by 2006 they were growing again. Hidden costs associated with ELECTRA's power service remained in the range of 1.0 to 1.5 percent of GDP for much of this period, making them material at the macroeconomic level (figure 5).

Table 5. Benchmarking power indicators, 2006

\begin{tabular}{|c|c|c|c|c|}
\hline & Unit & Low-income countries & Cape Verde & $\begin{array}{l}\text { Middle-income } \\
\text { countries }\end{array}$ \\
\hline Installed power generation capacity & MW/million people & 24.41 & 153.9 & 796.2 \\
\hline Power consumption & kWh/capita & 99.5 & 89.0 & 4,473 \\
\hline Power outages & Day/year & 40.6 & 150.4 & 5.6 \\
\hline Firms' reliance on own generator & $\%$ consumption & 17.7 & 4.6 & 0.5 \\
\hline $\begin{array}{l}\text { Firms' value lost due to power } \\
\text { outages }\end{array}$ & $\%$ sales & 6.1 & 8.9 & 0.8 \\
\hline Access to electricity & $\%$ population & 15.4 & 66.0 & 59.9 \\
\hline Urban access to electricity & $\%$ population & 71 & - & 83.7 \\
\hline Rural access to electricity & $\%$ population & 12 & - & 33.4 \\
\hline Growth access to electricity & $\%$ population/year & 1.4 & - & 1.8 \\
\hline Revenue collection & $\%$ billings & 88.2 & 86.9 & 99.9 \\
\hline Distribution losses & $\%$ production & 22.1 & 21.5 & 15.7 \\
\hline Cost recovery & $\%$ total cost & 90.0 & 71.3 & 125.7 \\
\hline \multirow[t]{2}{*}{ Total hidden costs as $\%$ of revenue } & $\%$ & 67.5 & 72.3 & 3.5 \\
\hline & & $\begin{array}{c}\text { Countries using } \\
\text { predominantly thermal } \\
\text { generation }\end{array}$ & Cape Verde & $\begin{array}{l}\text { Other developing } \\
\text { regions }\end{array}$ \\
\hline Power tariff (residential at $75 \mathrm{kWh}$ ) & U.S. cents & 16.0 & 25.1 & $5.0-10.0$ \\
\hline
\end{tabular}

Source: Eberhard and others 2008. Derived from the AICD electricity database (http://www.infrastructureafrica.org/aicd/tools/data).

Note: $\mathrm{GWh}=$ gigawatt-hour; kWh = kilowatt-hour; MW = megawatts. 
CAPE VERdE's INFRASTRUCTURE: A CONTINENTAL PERSPECTIVE

Table 6. Evolution of hidden costs associated with ELECTRA's power operations

\begin{tabular}{|c|c|c|c|c|c|c|c|}
\hline & $\begin{array}{l}\text { Load } \\
\text { served }\end{array}$ & $\begin{array}{l}\text { System } \\
\text { losses }\end{array}$ & $\begin{array}{l}\text { Collection } \\
\text { ratio }\end{array}$ & $\begin{array}{c}\text { Average total } \\
\text { cost }\end{array}$ & $\begin{array}{l}\text { Average effective } \\
\text { tariff }\end{array}$ & $\begin{array}{l}\text { Total hidden } \\
\text { costs }\end{array}$ & $\begin{array}{l}\text { Total hidden } \\
\text { costs }\end{array}$ \\
\hline & (GWh/year) & $(\%)$ & $(\%)$ & $(\$ / k W h)$ & (\$/kWh) & (\$ million/year) & (\% revenue) \\
\hline 2001 & 96 & 22.7 & 91.0 & 0.23 & 0.118 & 14.5 & 129.0 \\
\hline 2002 & 117 & 17.0 & 89.6 & 0.23 & 0.124 & 16.1 & 111.0 \\
\hline 2003 & 133 & 17.9 & 88.1 & 0.27 & 0.179 & 16.8 & 73.4 \\
\hline 2004 & 147 & 18.5 & 96.5 & 0.27 & 0.192 & 16.0 & 57.5 \\
\hline 2005 & 162 & 17.3 & 89.3 & 0.27 & 0.192 & 18.5 & 63.5 \\
\hline 2006 & 165 & 21.5 & 86.9 & 0.30 & 0.214 & 25.0 & 72.3 \\
\hline 2007 & 174 & 25.2 & 96.6 & 0.40 & 0.273 & 34.8 & 76.5 \\
\hline 2008 & 181 & 26.8 & 92.0 & 0.42 & 0.321 & 34.9 & 52.6 \\
\hline 2009 & 185 & 26.1 & 92.8 & 0.41 & 0.330 & 31.6 & 44.8 \\
\hline
\end{tabular}

Source: Derived from ELECTRA Annual Reports 2001-09.

Note: $\mathrm{kWh}=$ kilowatt-hour; $\mathrm{GWh}=$ gigawatt-hour.

Figure 4. Trend for oil and electricity prices in Cape Verde

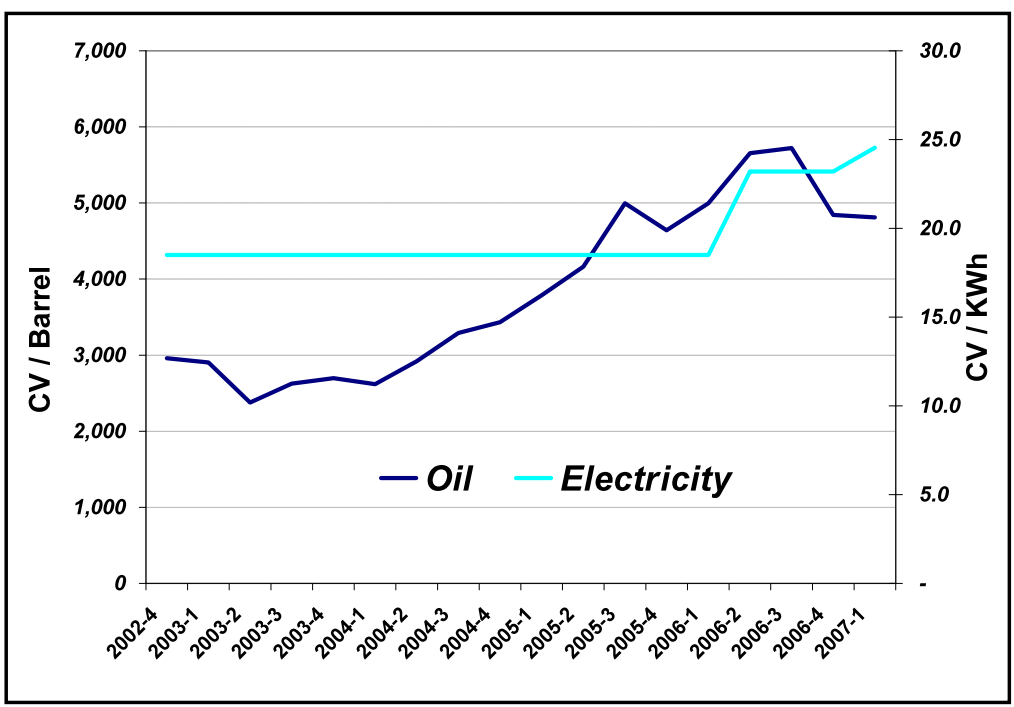

Source: Derived from ELECTRA Annual Reports 2001-09. 
Figure 5. Evolution of hidden costs in Cape Verde's power sector

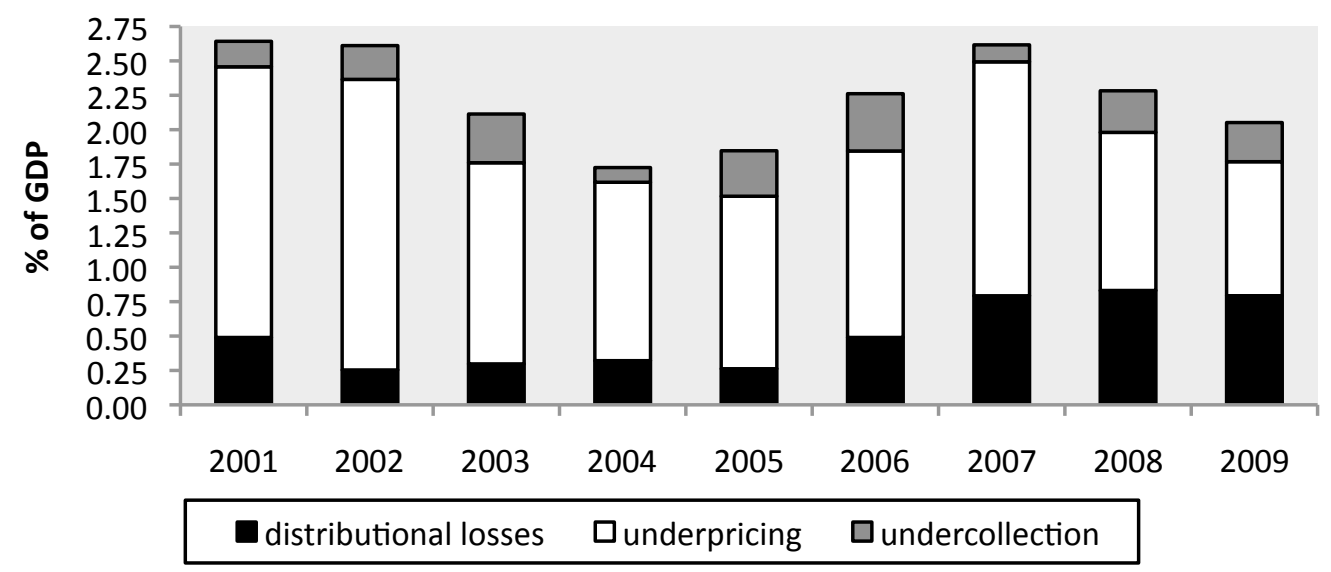

Source: Derived from ELECTRA Annual Reports 2001-09.

\section{Water supply and sanitation}

\section{Achievements}

Water and sewerage services in Cape Verde are also provided by the multiutility ELECTRA to the islands of São Vicente, Sal, Boavista, and the city of Praia. As noted above, this utility provides power service throughout the archipelago. In the rest of the country, water service is provided directly by local municipalities. (See the power section, above, for more on the institutional and operational issues affecting ELECTRA.)

\section{Challenges}

Cape Verde has relatively good access to utility water but relies heavily on standposts. About 70 percent of the population has access to utility water, comparable to the benchmark for African middleincome countries. In contrast to other middle-income countries, however, about half of those accessing utility water do so through standposts. Relative to low-income countries, access to both private taps and standposts is substantially higher, and there is noticeably less reliance on wells and boreholes.

Access patterns to sanitation are split, more or less, in two: half the population enjoys high-end solutions while the other half receives little service of any kind. On the one hand, coverage of flush toilets, at almost 50 percent, is slightly above the benchmark for middle-income countries in Africa. On the other hand, 50 percent of the population has no access to sanitation of any kind, which is even worse than the benchmark for low-income countries in Africa. Less than 10 percent of the population has access to latrines. Given Cape Verde's relatively good performance on household service coverage, these figures suggest that sanitation has been neglected relative to other household services. Clearly, the country has failed to develop a second-best sanitation alternative for citizens without access to a flush toilet.

Cape Verde has by far the most expensive water tariffs in Africa-and among the most expensive in the world-at over $\$ 3 / \mathrm{m}^{3}$. These high prices reflect the scarcity of water resources, which has forced the country to rely on desalination for approximately 85 percent of production. Moreover, the cost of the energy-intensive desalination process is particularly high due to its dependence on power generation, whose high costs in turn reflect reliance on small-scale diesel generation and expensive imported oil. The 
high cost of water in Cape Verde is largely a reflection of local hydrology; little can be done to alter it, other than adopting lower-cost technologies for power generation. Reflecting increases in the price of oil, water tariffs increased further to over $\$ 4 / \mathrm{m}^{3}$ in 2008 . It is difficult to evaluate the extent to which water tariffs fully cover costs. Since ELECTRA is a multi-utility, it is not possible to correctly allocate energy costs between the power and water operations of the company. For this analysis, energy costs have been fully allocated to the power sector, which may overestimate the underpricing of power and underestimate the underpricing of water. (See the power section for a more detailed discussion of the pricing challenges facing ELECTRA.)

ELECTRA's operational performance does not compare favorably with its middle-income peers. Domestic water consumption in Cape Verde, at around 35 liters per capita per day, is close to subsistence levels and just about half that found in the low-income peer group. This finding is consistent with the extreme shortage and high cost of water on the islands. As of 2006 performance on key operational parameters such as revenue collection and distribution losses lagged well behind those of the African middle-income peer group and were more comparable to the low-income group. Since then, distribution losses have further deteriorated—reaching 35 percent by 2009-which is cause for concern, given the high cost of water. Over the same period, however, the collection ratio improved, nearing 99 percent (table 6). Thanks to improvements in revenue collection, hidden costs fell significantly in the late 2000s, to around 0.15 percent of GDP (figure 7).

Figure 6. Comparison of water tariffs across Africa

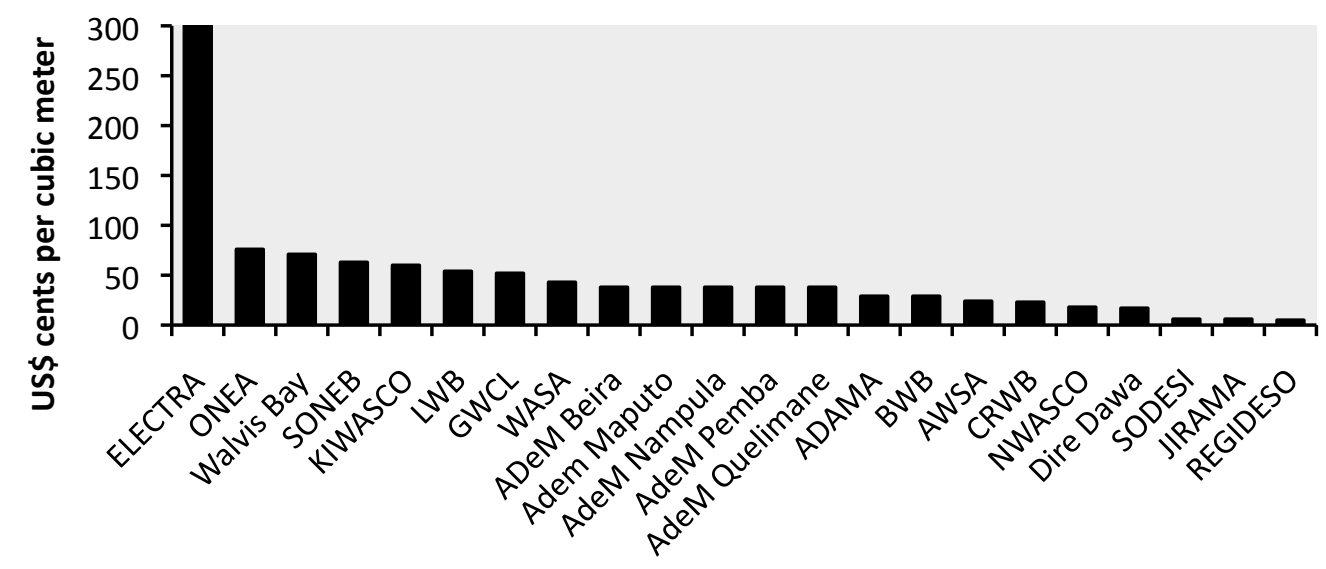

Source: Derived from Banerjee, Foster, and others (2008).

Note: Horizontal axis presents names of selected water companies in region. 
Table 7. Benchmarking water and sanitation indicators, 2006

\begin{tabular}{|c|c|c|c|c|}
\hline & Unit & Low-income countries & Cape Verde & $\begin{array}{l}\text { Middle-income } \\
\text { countries }\end{array}$ \\
\hline Access to piped water & $\%$ рор & 10.1 & 34.9 & 56.4 \\
\hline Access to standposts & $\%$ pop & 16.1 & 36.5 & 20.4 \\
\hline Access to wells/boreholes & $\%$ рор & 38.3 & 10.1 & 10.1 \\
\hline Access to surface water & $\%$ pop & 33.8 & 14.3 & 13.9 \\
\hline Access to flush toilets & $\%$ рор & 5.3 & 48.7 & 44.0 \\
\hline Access to latrines & $\%$ pop & 57.2 & 8.3 & 33.9 \\
\hline Open defecation & $\%$ pop & 37.1 & 45.4 & 15.8 \\
\hline Domestic water consumption & liter/capita/day & 72.4 & 34.6 & n.a. \\
\hline Revenue collection & $\%$ sales & 96.0 & 93.3 & 99.2 \\
\hline Distribution losses & $\%$ production & 33.0 & 29.8 & 23.1 \\
\hline Operating cost recovery & $\%$ total costs & 56.0 & 484.8 & 80.6 \\
\hline \multirow[t]{2}{*}{ Total hidden costs as $\%$ of revenue } & $\%$ & 130.0 & 10.2 & 84.9 \\
\hline & & $\begin{array}{l}\text { Countries with scarce } \\
\text { water resources }\end{array}$ & Cape Verde & $\begin{array}{l}\text { Other developing } \\
\text { regions }\end{array}$ \\
\hline Residential tariff & U.S. cents per m³ & 309.30 & 60.26 & \multirow{2}{*}{$3.0-60.0$} \\
\hline Nonresidential tariff & U.S. cents per $\mathrm{m}^{3}$ & 453.30 & 120.74 & \\
\hline
\end{tabular}

Source: Banerjee, Skilling, and others 2008; Morella, Foster, and Banerjee 2008. Derived from the AICD water and sanitation utilities database (http://www.infrastructureafrica.org/aicd/tools/data). Access data comes from DHS (2005) as presented by the WHO-UNICEF Joint Monitoring Programme.

Note: $\mathrm{m}^{3}=$ cubic meter.

n.a. $=$ Not applicable.

Table 8. Evolution of hidden costs associated with ELECTRA's water operations

\begin{tabular}{|c|c|c|c|c|c|c|c|}
\hline & $\begin{array}{l}\text { Volume } \\
\text { produced }\end{array}$ & $\begin{array}{l}\text { Distribution } \\
\text { losses }\end{array}$ & $\begin{array}{l}\text { Collection } \\
\text { ratio }\end{array}$ & $\begin{array}{c}\text { Average } \\
\text { operating cost }\end{array}$ & $\begin{array}{c}\text { Average effective } \\
\text { tariff }\end{array}$ & $\begin{array}{l}\text { Total hidden } \\
\text { costs }\end{array}$ & $\begin{array}{l}\text { Total hidden } \\
\text { costs }\end{array}$ \\
\hline & (Mm³/year) & $(\%)$ & $(\%)$ & (\$/kWh) & $(\$ / k W h)$ & (\$ million/year) & (\% revenue) \\
\hline 2000 & 3.0 & 25.9 & 91.0 & 0.86 & 1.70 & 0.6 & 16.4 \\
\hline 2001 & 3.0 & 22.8 & 91.0 & 0.91 & 1.64 & 0.5 & 12.5 \\
\hline 2002 & 3.6 & 27.6 & 95.9 & 0.73 & 1.72 & 0.6 & 13.7 \\
\hline 2003 & 4.0 & 29.1 & 83.9 & 0.84 & 2.83 & 2.2 & 28.1 \\
\hline 2004 & 4.1 & 29.7 & 94.4 & 1.13 & 3.13 & 1.6 & 17.8 \\
\hline 2005 & 4.3 & 30.8 & 98.0 & 1.10 & 3.17 & 1.4 & 15.4 \\
\hline 2006 & 4.3 & 29.8 & 93.3 & 0.66 & 3.20 & 1.8 & 18.1 \\
\hline 2007 & 4.2 & 30.6 & 104.8 & 1.27 & 3.83 & 1.5 & 13.0 \\
\hline 2008 & 4.2 & 31.5 & 98.1 & 0.55 & 4.31 & 2.0 & 16.4 \\
\hline 2009 & 4.5 & 35.3 & 99.1 & 0.76 & 4.43 & 2.6 & 21.9 \\
\hline
\end{tabular}

Source: Derived from ELECTRA Annual Reports 2001/09.

Note: $\mathrm{Mm}^{3}=$ millions of cubic meters; $\mathrm{kWh}=$ kilowatt-hour. 
Figure 7. Evolution of hidden costs in Cape Verde's water sector

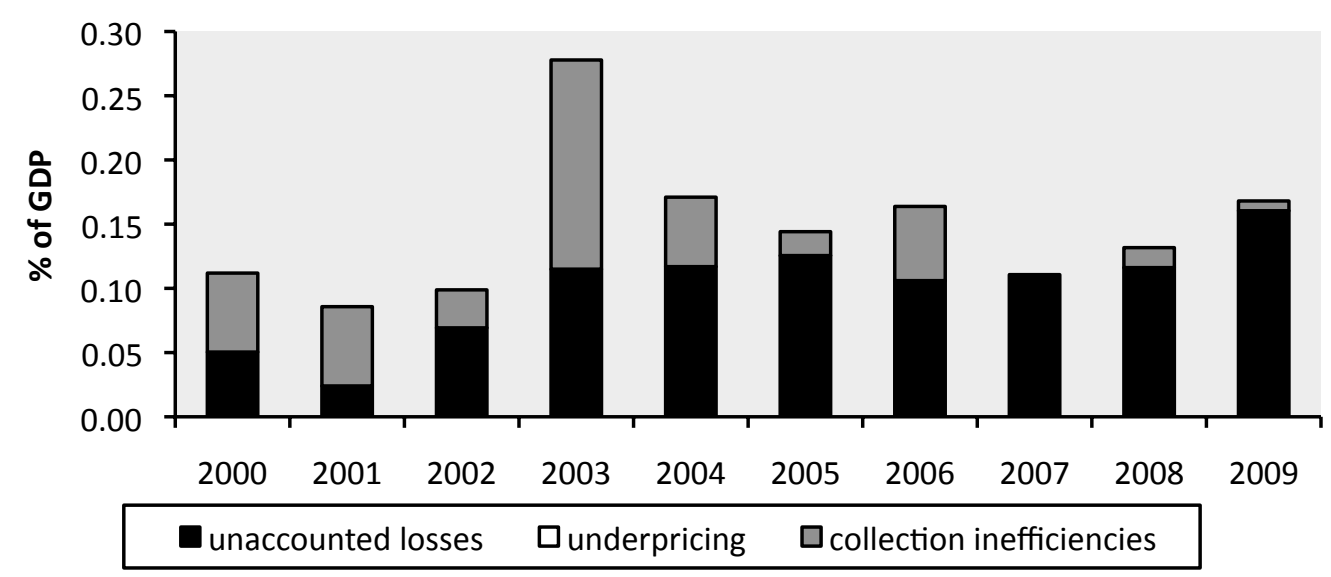

Source: Derived from ELECTRA Annual Reports 2001-09.

\section{Information and communications technologies}

\section{Achievements}

Cape Verde has made substantial progress in expanding access to ICT (table 9, top). The percentage of the population with a mobile phone rose from 17 percent in 2005 to 69 percent in 2009. In 2005 just 5 out of 100 people were Internet users; in 2009 this number was 22 - the second-highest in Sub-Saharan Africa (after Mauritius).

Significant reform of the ICT sector has taken place since the mid-2000s. A new telecommunications law was introduced in 2005 that ended the fixed and international communications monopoly of Cape Verde Telecom (CVT). The National Agency for Communications (Agência Nacional das Comunicações, ANAC), the industry regulator, was created in 2006. A second mobile operator, T+ Telecomunicações, was launched in December 2007 as a competitor to CVT. 
Table 9. Benchmarking ICT indicators

\begin{tabular}{|c|c|c|c|c|c|c|}
\hline & Unit & Cape Verde & Cape Verde & $\begin{array}{l}\text { Lower-middle- } \\
\text { income group }\end{array}$ & $\begin{array}{c}\text { Sub-Saharan } \\
\text { Africa }\end{array}$ & Cape Verde \\
\hline & & 2005 & 2008 & 2008 & 2008 & 2009 \\
\hline GSM coverage & $\%$ population & 74 & 83 & 77 & 56 & 84 \\
\hline International bandwidth & Mbps/capita & 35 & 310 & 153 & 34 & 604 \\
\hline Internet & Users/100 people & 5 & 10 & 14 & 7 & 22 \\
\hline Landline & Lines/100 people & 15 & 14 & 14 & 2 & 14 \\
\hline Mobile phone & Subscribers/100 people & 17 & 56 & 47 & 33 & 68 \\
\hline \multicolumn{2}{|c|}{ Price of monthly mobile basket } & 18.1 & 16.7 & 8.4 & 11.8 & 20.5 \\
\hline \multicolumn{2}{|c|}{ Price of monthly fixed-line basket } & 4.7 & 5.4 & 4.8 & 11.6 & 9.1 \\
\hline \multicolumn{2}{|c|}{ Price of monthly fixed broadband Internet package } & - & 45 & 31.4 & 100.1 & 32 \\
\hline \multirow{2}{*}{\multicolumn{2}{|c|}{ Price of a call to the United States $(\$ / \mathrm{min})$}} & 2.0 & 1.3 & - & 0.7 & 0.86 \\
\hline & & - & 1.3 & - & 1.02 & 0.86 \\
\hline
\end{tabular}

Source: Ampah and others 2009; World Bank ICT at a Glance Database, National Communications Agency (ANAC).Derived from the AICD national database (http://www.infrastructureafrica.org/aicd/tools/data).

Note: ICT = information and communications technology; GSM = global system for mobile communications; Mbps = megabits per second.

n.a. $=$ Not applicable.

$-=$ Not available

\section{Challenges}

Cape Verde faces the challenge of increasing ICT access as a small island developing state with only recent, limited experience in sector liberalization. While the experience of introducing competition into the mobile sector has been positive, with a significant increase in both penetration and coverage, access still lags behind other countries with similar levels of income. Nascent regulatory skills and the small size of the market constrain competition, resulting in relatively high tariffs (table 9, bottom). Fixed-line prices have been rebalanced, with subscription and local call charges rising sharply while international call charges have fallen. On the other hand, prepaid mobile prices have actually risen since the introduction of competition. This has been mitigated to some extent by the introduction of per-second tariffs-but at the cost of more expensive prices for heavy users. The one bright spot in this picture is broadband pricing, which has fallen.

To better utilize submarine cables, key access facilities must be prevented from establishing monopolistic bottlenecks. In the Internet market the incumbent controls the fixed-telephone network necessary for providing broadband access. Cape Verde has been fortunate to have a high-speed undersea fiber-optic connection through the Atlantis 2 cable since 2000. But the incumbent controls this and is also an investor in a second cable, the WACS (West African Cable System), scheduled for launch in 2011. Regulatory tools are needed to enhance access through these bottleneck facilities. Six of the most populated islands were connected by a submarine cable fiber-optic system in 2002 , with the rest to be connected in 2011.

Competition in both mobile and broadband markets should intensify with the planned introduction of third-generation (3G) mobile networks and a third mobile operator. This should boost the country's relatively high ICT position within the region (table 9) and enhance the possibility of meeting Cape Verde's ICT development goals. 
There is still significant scope for commercially viable expansion of global system for mobile communications (GSM) coverage into rural areas. Cape Verde has made substantial progress in expanding the percentage of the population living within range of a GSM signal, which rose from 62 percent in 2005 to 83 percent in 2008. Nevertheless, this value falls short of simulations, suggesting it would be feasible to provide a GSM signal to almost 100 percent of the population on a commercially viable basis (figure 8). Most islands would even be commercially viable for universal access to limitedperformance WIMAX ${ }^{3}$ broadband via public telecenter facilities (figure 9).

Figure 8. Almost all of Cape Verde's population could be commercially served with a GSM signal

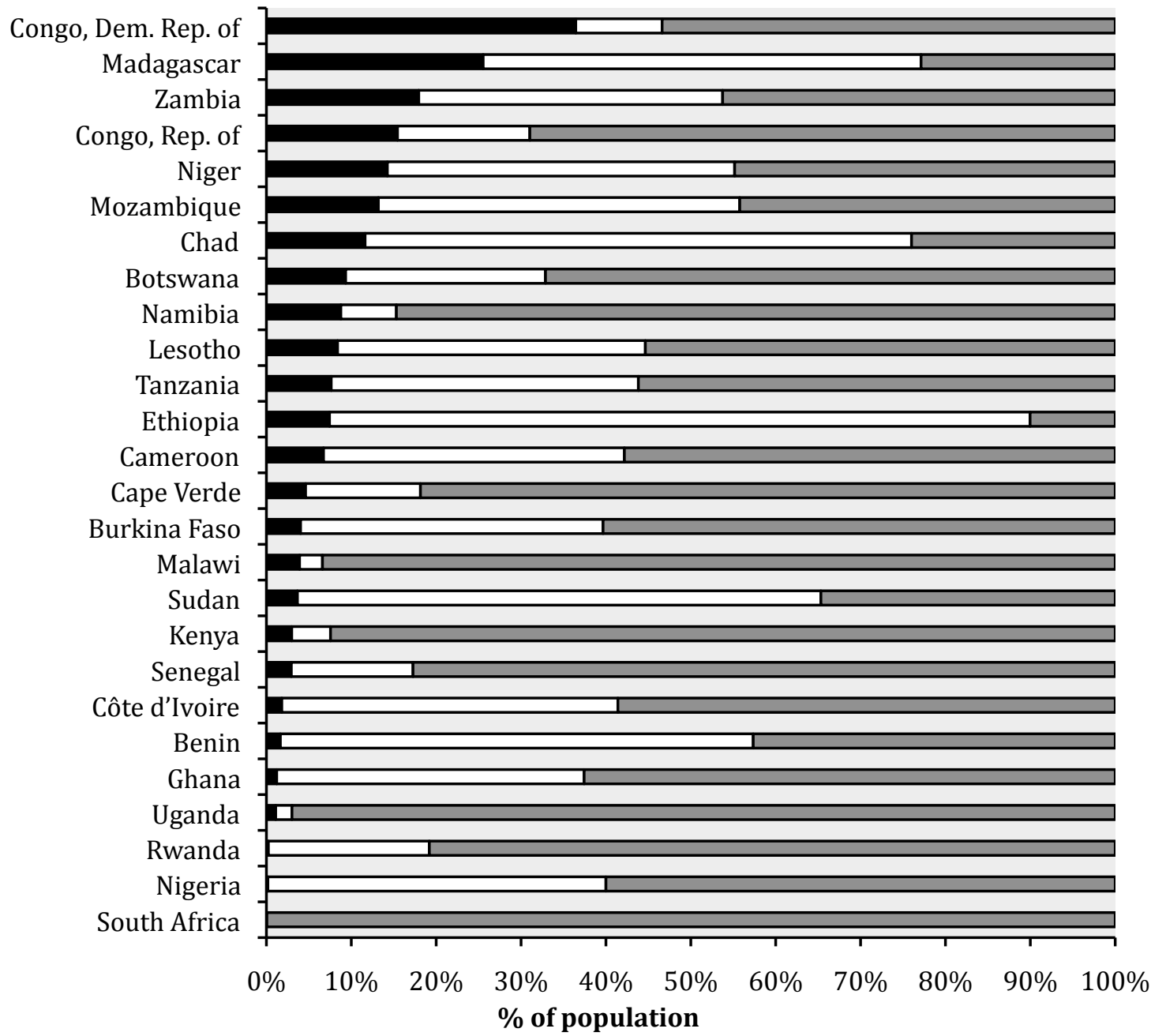

\section{- coverage gap $\quad$ aefficient market gap $\quad$ Dexisting access}

Source: Mayer and others 2009.

Note: GSM = global system for mobile communications. Bar segments in gray represent the percentage of population currently covered by voice infrastructure as of the third quarter of 2006.

Bar segments in white represent the efficient-market gap—the percentage of the population for whom voice telecommunications services are commercially viable given efficient and competitive markets.

Bar segments in black represent the coverage gap-the percentage of the population for whom services are not viable without subsidy.

${ }^{3}$ WIMAX $=$ Worldwide interoperability for microwave access. 
Figure 9. Only isolated pockets of Cape Verde's territory are not commercially viable for voice and broadband

a. GSM voice signal
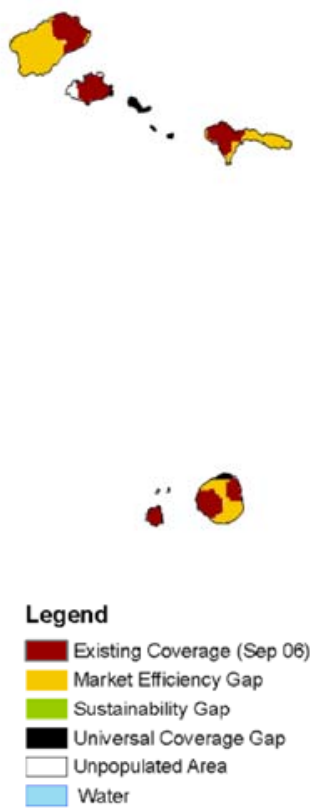

b. Limited-performance broadband (WIMAX)
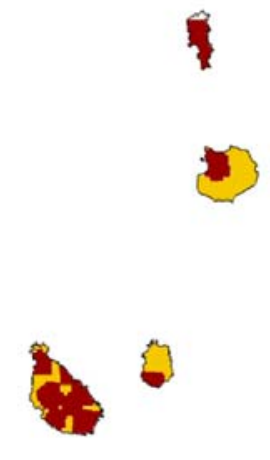

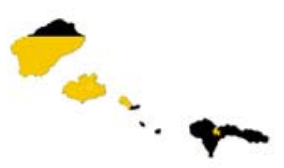

1

Source: Mayer and others 2009.

Note: Existing coverage relates to base year of 2006. GSM = global system for mobile communications; WIMAX = worldwide interoperability for microwave access.

\section{Financing Cape Verde's infrastructure}

Cape Verde already dedicates a substantial volume of its resources to infrastructure. Average annual spending in the mid-2000s amounted to $\$ 147$ million annually (table 10). About half of this amount is dedicated to the transport sector (and to air transport in particular). The substantial weight of transport spending reflects the challenging geographical characteristics of the country. Power comes in second place, at $\$ 44$ million annually, followed by water and sanitation, at \$25 million annually. Existing spending is skewed toward capital expenditure, which accounts for more than 70 percent of the total.

\section{How much does Cape Verde spend on infrastructure?}

Cape Verde's spending amounted to a remarkable 15 percent of GDP in 2006 (figure 10). This makes Cape Verde one of the highest-spending African countries on infrastructure relative to its national income, with a spending effort about twice the average level for middle-income countries in Africa. Indeed, this level of effort approaches that of China during the 2000s, when 15 percent of the country's GDP was invested in infrastructure (not counting O\&M). Compared to other middle-income countries in Africa, Cape Verde receives a relatively large amount of official development assistance (ODA) to support capital investments in water and sanitation and especially transport (figure 11). Sectoral 
investment patterns are also very distinct, heavily skewed toward transport, while in other countries they are more skewed toward ICT.

Table 10. Financial flows to Cape Verde's infrastructure, average 2001 to 2006

\$ millions per year

\begin{tabular}{|c|c|c|c|c|c|c|c|}
\hline & \multicolumn{2}{|c|}{ O\&M } & \multicolumn{4}{|c|}{ Capital expenditure } & \multirow[b]{2}{*}{$\begin{array}{c}\text { Total } \\
\text { spending }\end{array}$} \\
\hline & Public sector & Public sector & ODA & $\begin{array}{l}\text { Non-OECD } \\
\text { financiers }\end{array}$ & PPI & Total capex & \\
\hline ICT & 0 & 0 & 1 & 1 & 0 & 2 & 2 \\
\hline Power & 34 & 9 & 0 & 1 & 0 & 10 & 44 \\
\hline Transport & 2 & 28 & 45 & 1 & 0 & 74 & 77 \\
\hline WSS & 4 & 12 & 9 & 0 & 0 & 22 & 25 \\
\hline Total & 40 & 50 & 55 & 3 & 0 & 107 & 147 \\
\hline
\end{tabular}

Source: Derived from Foster and Briceño-Garmendia (2009).

Note: Capex = capital expenditure; ICT = information and communications technology; O\&M = operations and maintenance; ODA = official development assistance; OECD = Organisation for Economic Co-operation and Development; PPI = private participation in infrastructure; WSS $=$ water supply and sanitation.

Figure 10. Cape Verde's existing infrastructure spending is very high in GDP terms

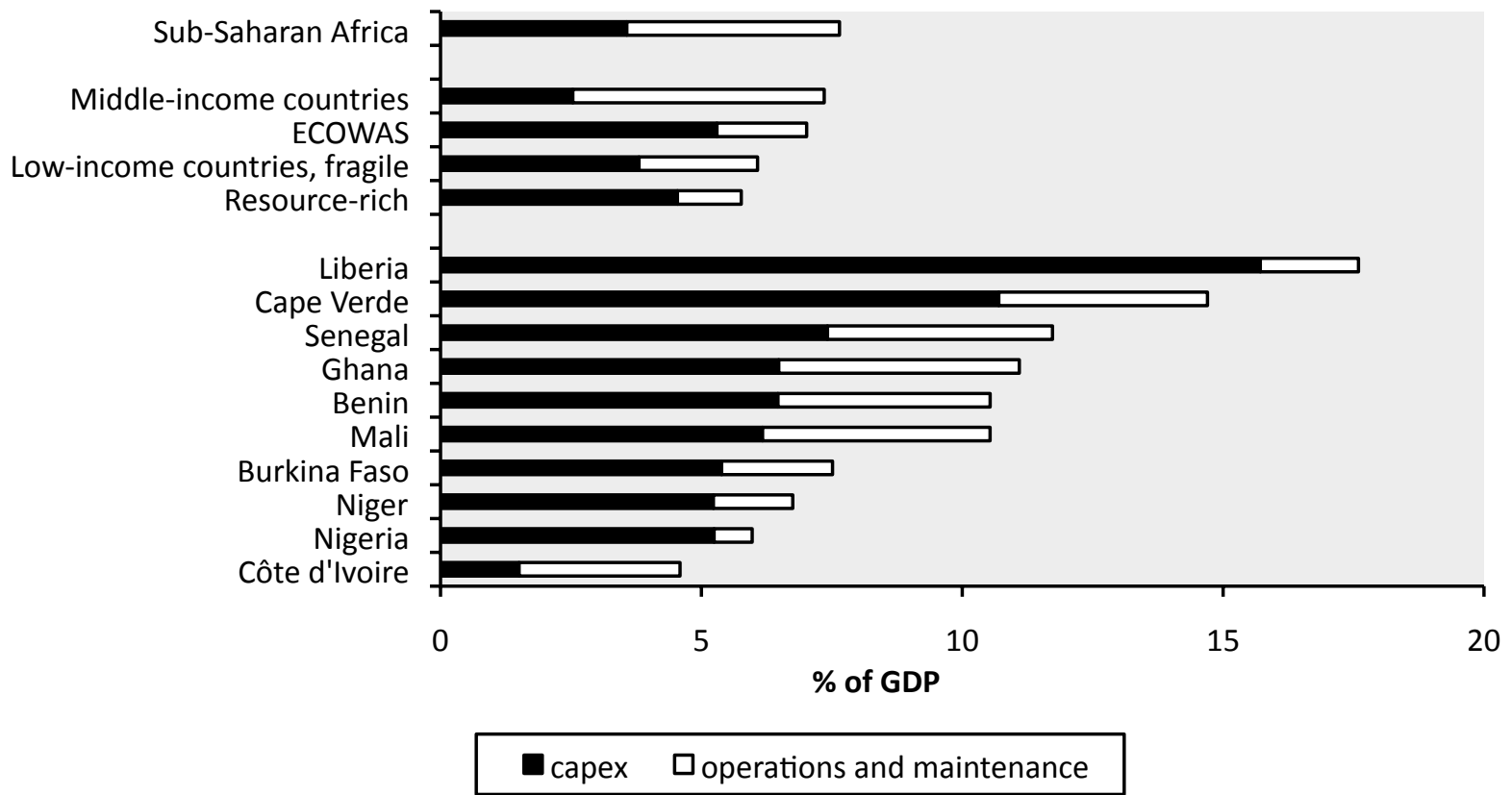

Source: Derived from Foster and Briceño-Garmendia (2009).

Note: Capex = Capital expenditure; ECOWAS = Economic Community of West African States; GDP = gross domestic product. 
Figure 11. Cape Verde's pattern of capital investment in infrastructure differs from that of comparator countries

Investment in infrastructure sectors as percentage of GDP, by source

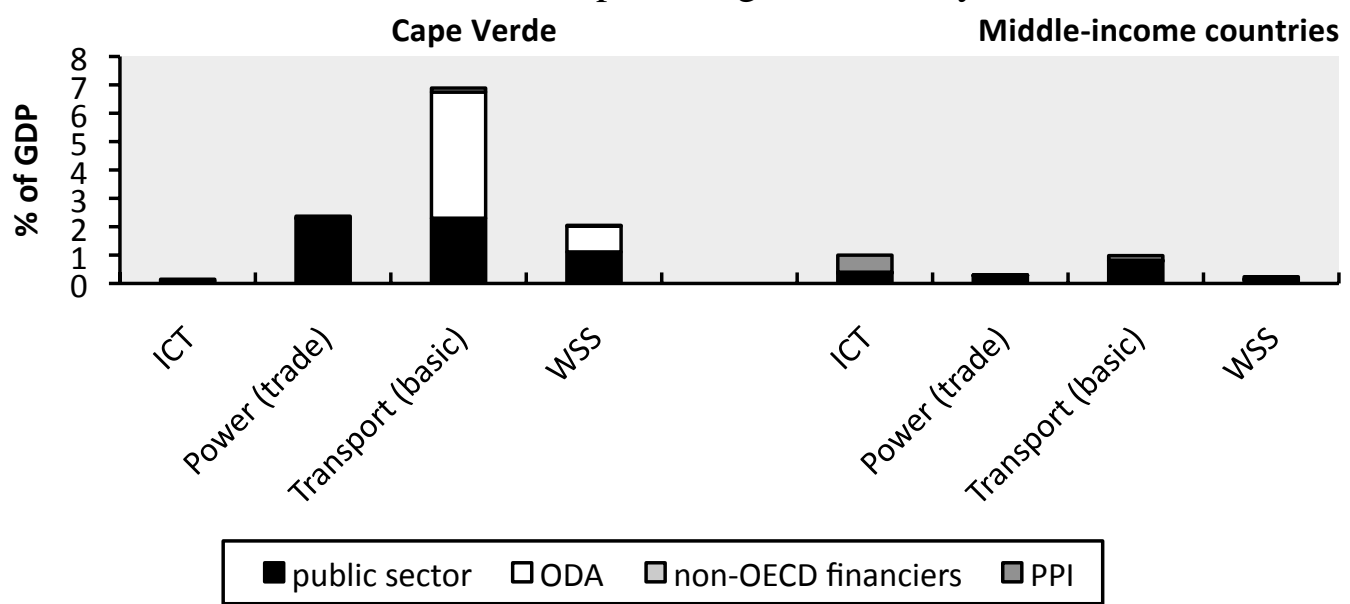

Source: Derived from Briceño-Garmendia, Smits, and Foster (2008).

Note: Private investment includes self-financing by households. GDP = gross domestic product; ICT = information and communications technology; $\mathrm{ODA}$ = official development assistance; $\mathrm{OECD}=$ Organisation for Economic Co-operation and Development; $\mathrm{PPI}$ = private participation in infrastructure; WSS = water supply and sanitation.

\section{How much more can be done within the existing resource envelope?}

Some $\$ 50$ million of additional resources could be recovered each year by improving efficiency (table 11). By far the largest potential source of efficiency gains is the power sector, with potential efficiency gains valued at \$25 million annually if underpricing and distribution losses are addressed. Low capital budget execution is also a significant issue, affecting both the transport and water sectors to the tune of $\$ 12$ million annually.

Table 11. Potential gains from greater operational efficiency

\begin{tabular}{lrrrrr} 
\$ millions per year & & & & & \\
& ICT & Power & Transport & WSS & Total \\
\hline Underpricing & - & 15 & n.a. & 0 & 15 \\
\hline Overstaffing & n.a. & 3 & - & 1 & 4 \\
\hline Distribution losses & - & 12 & - & 2 & 15 \\
\hline Undercollection & - & 4 & n.a. & 0 & 4 \\
\hline Low budget execution & 0 & 1 & 5 & 6 & 12 \\
\hline Total & 0 & 35 & 5 & 9 & 50 \\
\hline
\end{tabular}

Source: Derived from Foster and Briceño-Garmendia (2009).

Note: ICT = information and communications technology; WSS = water supply and sanitation.

n.a. $=$ Not applicable.

$-=$ Not available. 
The extent of underpricing is exceptionally high for power, but apparently not for water. Despite Cape Verde's relatively high power tariffs, the extent of underpricing in the power sector amounts to almost 1 percent of GDP, representing an economic burden almost twice as large as that found in the middle-income peer group (figure 12). The difficulties of cost allocation make it difficult to reliably establish the extent to which water is underpriced, although with tariffs in excess of $\$ 4 / \mathrm{m}^{3}$, this does not appear to be a major concern (in contrast to other middle-income countries).

\section{Figure 12. Underpricing of power and water does not seem to be an issue in Cape Verde}

Financial burden of underpricing in 2006, as percentage of GDP

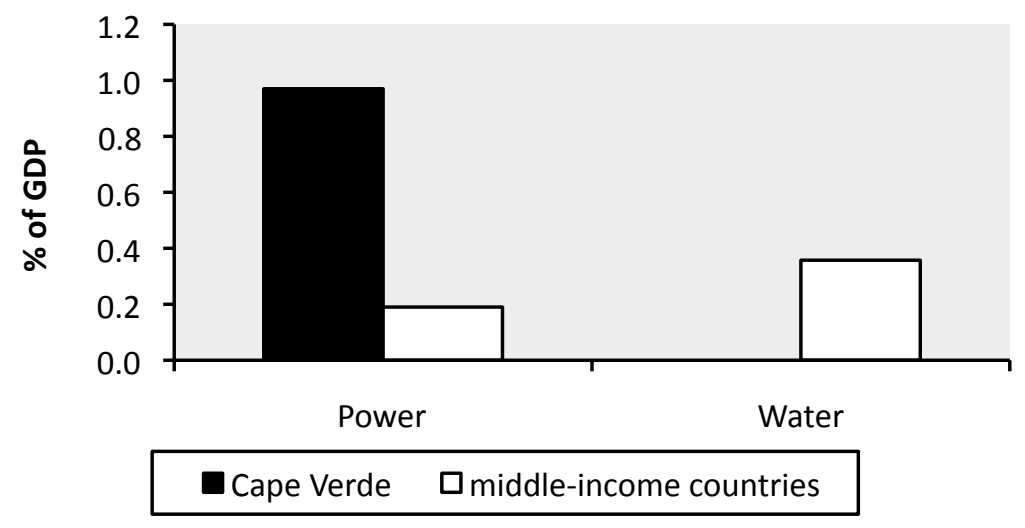

Source: Derived from Briceño-Garmendia, Smits, and Foster (2008). Note: GDP = gross domestic product.

Underpricing of power and water represents an implicit subsidy to these sectors that is highly regressive in its distributional incidence. This to a large extent mirrors the distributional incidence of access to power and water services in the country. A recent study found that-in common with most other countries in Africa - subsidized utility tariffs in Cape Verde are highly regressive, with an omega value well below 1 (figure 13). This means that the share of power subsidies that reach the poor is only half as much as what should reach them, given their share of the population, while the share of water subsidies that reach the poor is only a quarter of what it should be.

Although cost-recovery tariffs are high, they appear to be within the reach of household budgets, at least at very modest levels of subsistence consumption. Given the exceptionally high costs of producing power and water services in Cape Verde, and the already high level of tariffs, it is legitimate to ask whether full cost-recovery tariffs would be affordable to consumers. How expensive would utility bills become if cost-reflective tariffs were applied? With a cost-recovery power tariff of $\$ 0.41 / \mathrm{kWh}$ and a monthly subsistence consumption of $25 \mathrm{kWh}$, the associated power bill would come to $\$ 10.25$ per month. With a cost-recovery tariff of $\$ 4.43 / \mathrm{m}^{3}$ and a monthly subsistence consumption of $4 \mathrm{~m}^{3}$, the associated water bill would come to $\$ 17.72$ per month. Based on the distribution of household budgets in Cape Verde, monthly utility bills at these levels look to be affordable for just about the entire population (figure 14). 
Figure 13. Africa's electricity and water subsidies are highly regressive

a. Electricity

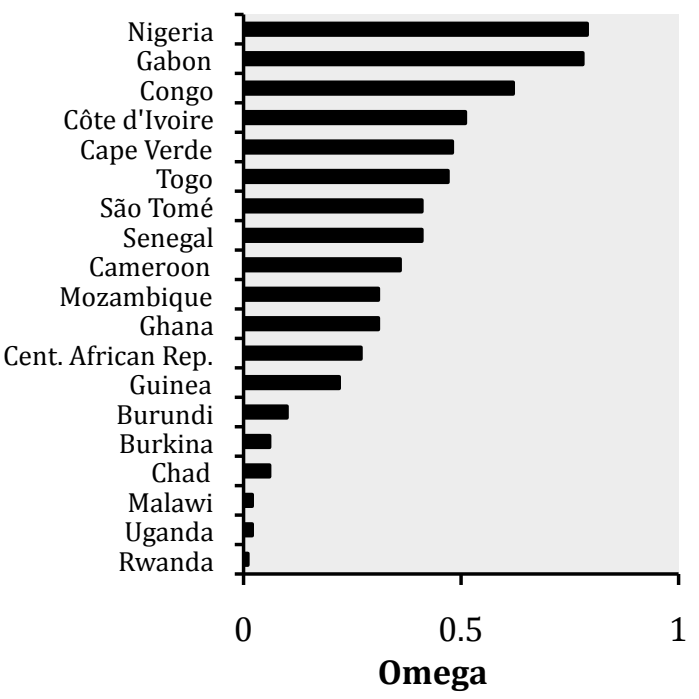

b. Water

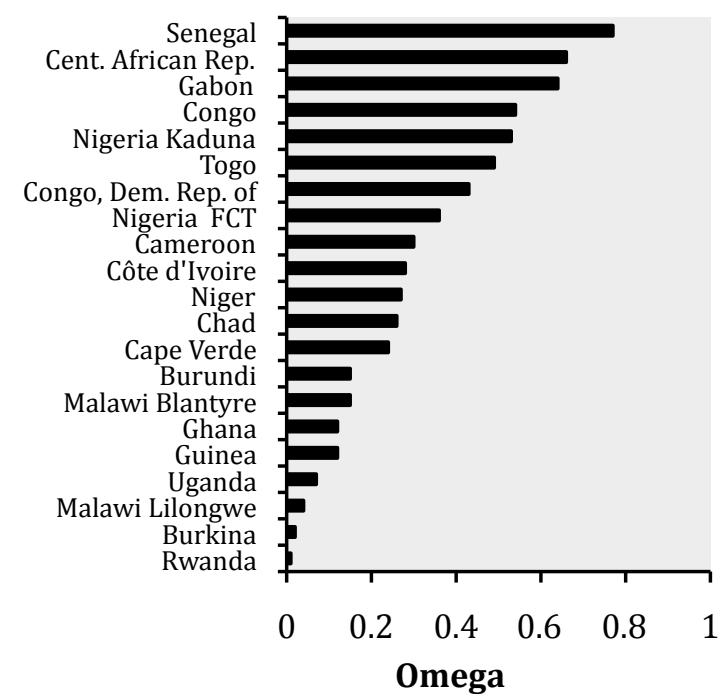

Source: Banerjee, Wodon, and others 2008.

Note: Omega is a measure of distributional incidence that measures the share of subsidies received by the poor as a percentage of their share in the population. The higher the value of omega, the better the distributional performance of the subsidy. Values of omega below 1 denote a regressive subsidy; values of omega above 1 denote a progressive subsidy.

Figure 14. Affordability in Cape Verde is much better than in other middle-income countries

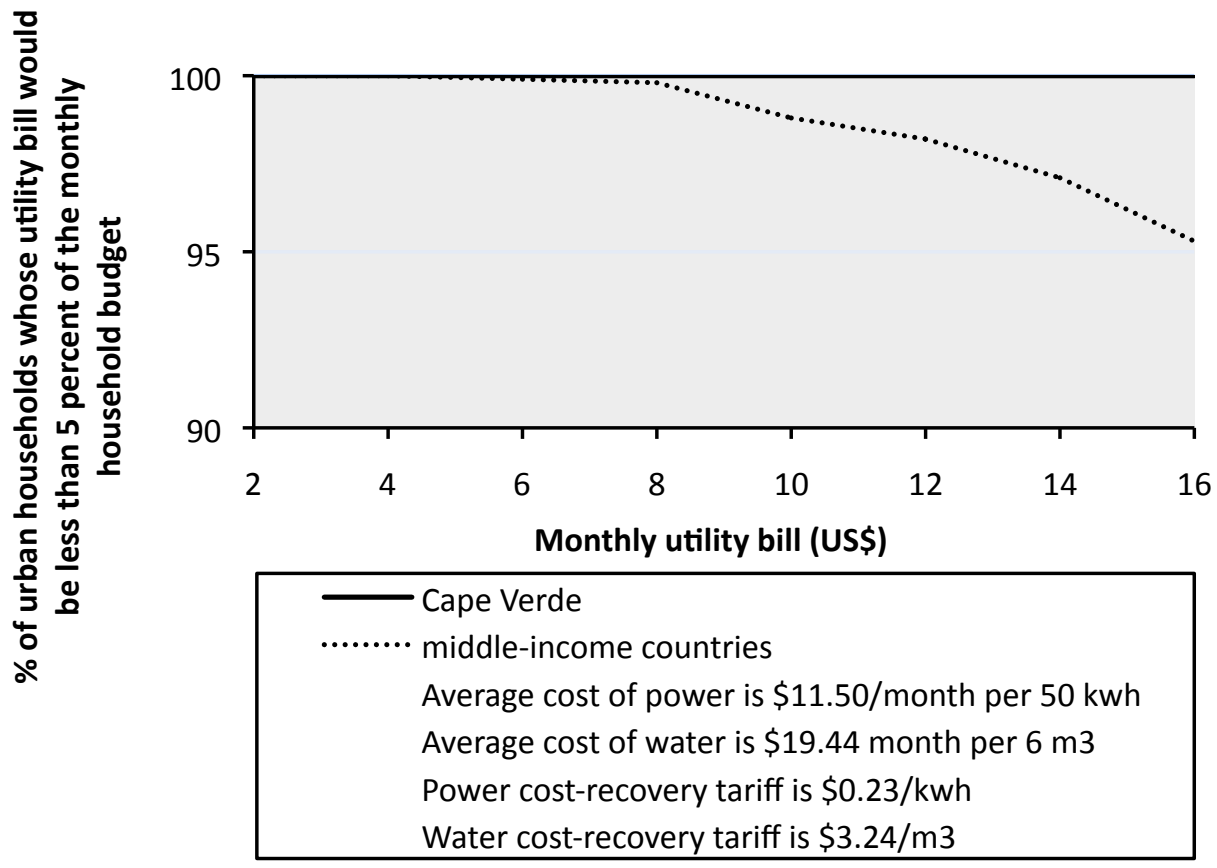

Source: Banerjee, Wodon, and others 2008.

Note: m3 =cubic meter; kwh = kilowatt-hour. 
ELECTRA's operational performance leads to substantial hidden costs compared to those of utilities in other African middle-income countries. Operational inefficiencies of power and water utilities cost Cape Verde a further \$23 million a year, equivalent to 1.5 percent of GDP. The annual value of inefficiencies in the power sector (at $\$ 19$ million) is substantially higher than for the water sector (at $\$ 4$ million). The burden of utility inefficiencies in Cape Verde is substantially higher than for the middleincome peer group (figure 15). In both sectors, it is high distribution losses (as opposed to low revenue collection) that are primarily responsible for the weak performance.

Figure 15. Cape Verde's utilities are highly inefficient relative to middle-income peers a. Uncollected bills and unaccounted losses in the power sector, as a
percentage of GDP

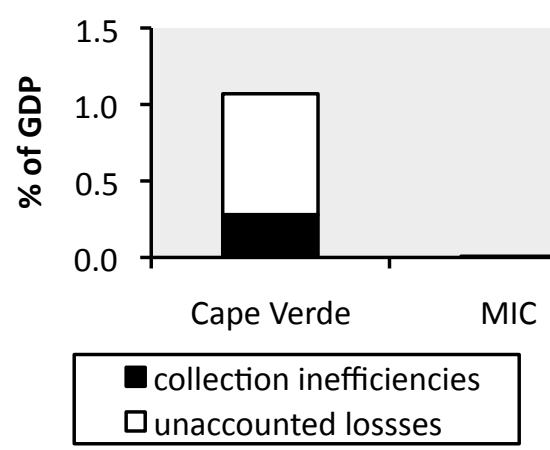

b. Uncollected bills and unaccounted losses in the water sector, as a percentage of GDP

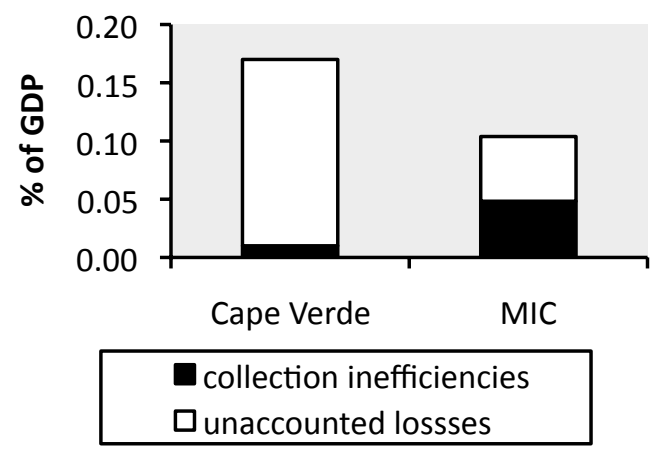

Source: Derived from Briceño-Garmendia, Smits, and Foster (2008).

Note: $\mathrm{GDP}=$ gross domestic product; $\mathrm{MIC}=$ middle-income countries .

In sum, Cape Verde dedicates an exceptionally high share of its national resources to the infrastructure sectors, reflecting in part the exceptionally high costs presented by the country's challenging economic geography. 


\section{References and bibliography}

This country report draws upon a wide range of papers, databases, models, and maps that were created as part of the Africa Infrastructure Country Diagnostic. All of these can be downloaded from the project website: http://www.infrastructureafrica.org. For papers go to the document page (http://www.infrastructureafrica.org/aicd/documents), for databases to the data page (http://www.infrastructureafrica.org/aicd/tools/data), for models go to the models page (http://www.infrastructureafrica.org/aicd/tools/models), and for maps to the map page (http://www.infrastructureafrica.org/aicd/tools/maps ). The references for the papers that were used to compile this country report are provided in the table below.

\section{General}

Africa's Infrastructure: A Time for Transformation (AICD Web site), http://www.infrastructureafrica.org. Banerjee, Sudeshna, Quentin Wodon, Amadou Diallo, Taras Pushak, Helal Uddin, Clarence Tsimpo, and Vivien Foster. 2008. “Access, Affordability, and Alternatives: Modern Infrastructure Services in Africa.” AICD Background Paper 2, Africa Region, World Bank, Washington, DC.

Estache, A., and M. Vagliasindi. 2007. "Infrastructure for Accelerated Growth for Ghana: Needs and Challenges.” Background Paper, Country Economic Memorandum, World Bank, Washington, DC.

Foster, Vivien, and Cecilia Briceño-Garmendia, eds. 2009. Africa's Infrastructure: A Time for Transformation. Paris and Washington, DC: Agence Française de Développement and World Bank.

Keener, S., and S. G. Banerjee. 2005. "Ghana: Poverty and Social Impact Analysis of Electricity Tariffs." ESMAP Technical Paper 088, World Bank, Washington, DC.

Lall, S., J. Sandefur, and H. G. Wang. 2008. "Can Industrial Development Bridge Ghana's Spatial Divide?" Mimeo, World Bank, Washington, DC.

\section{Growth}

Calderón, César. 2009. "Infrastructure and Growth in Africa." Policy Research Working Paper 4914, World Bank, Washington, DC.

Escribano, Alvaro, J. Luis Guasch, and Jorge Pena. 2010. “Assessing the Impact of Infrastructure Quality on Firm Productivity in Africa.” Policy Research Working Paper 5191, World Bank, Washington, DC.

Yepes, Tito, Justin Pierce, and Vivien Foster. 2009. "Making Sense of Africa's Infrastructure Endowment: A Benchmarking Approach.” Policy Research Working Paper 4912, World Bank, Washington, DC. 


\section{Financing}

Briceño-Garmendia, Cecilia, Karlis Smits, and Vivien Foster. 2008. "Financing Public Infrastructure in Sub-Saharan Africa: Patterns and Emerging Issues.” AICD Background Paper 15, Africa Region, World Bank, Washington, DC.

\section{Information and communic ations technologies}

Ampah, Mavis, Daniel Camos, Cecilia Briceño-Garmendia, Michael Minges, Maria Shkaratan, and Mark Williams. 2009. "Information and Communications Technology in Sub-Saharan Africa: A Sector Review.” AICD Background Paper 10, Africa Region, World Bank, Washington, DC.

Mayer, Rebecca, Ken Figueredo, Mike Jensen, Tim Kelly, Richard Green, and Alvaro Federico Barra. 2009. "Connecting the Continent: Costing the Needs for Spending on ICT Infrastructure in Africa.” AICD Background Paper 3, Africa Region, World Bank, Washington, DC.

\section{Irrigation}

Svendsen, Mark, Mandy Ewing, and Siwa Msangi. 2008. "Watermarks: Indicators of Irrigation Sector Performance in Africa.” AICD Background Paper 4, Africa Region, World Bank, Washington, DC.

You, L., C. Ringler, G. Nelson, U. Wood-Sichra, R. Robertson, S. Wood, G. Zhe, T. Zhu, and Y. Sun. 2009. "Torrents and Trickles: Irrigation Spending Needs in Africa.” AICD Background Paper 9, Africa Region, World Bank, Washington, DC.

\section{Power}

Eberhard, Anton, Vivien Foster, Cecilia Briceño-Garmendia, Fatimata Ouedraogo, Daniel Camos, and Maria Shkaratan. 2008. "Underpowered: The State of the Power Sector in Sub-Saharan Africa." AICD Background Paper 6, Africa Region, World Bank, Washington, DC.

Foster, Vivien, and Jevgenijs Steinbuks. 2009. "Paying the Price for Unreliable Power Supplies: In-House Generation of Electricity by Firms in Africa." Policy Research Working Paper 4913, World Bank, Washington, DC.

Rosnes, Orvika, and Haakon Vennemo. 2009. "Powering Up: Costing Power Infrastructure Spending Needs in Sub-Saharan Africa.” AICD Background Paper 5, Africa Region, World Bank, Washington, DC.

\section{Transport}

Bullock, Richard. 2009. “Off Track: Sub-Saharan African Railways.” AICD Background Paper 17, Africa Region, World Bank, Washington, DC. 
Carruthers, Robin, Ranga Rajan Krishnamani, and Siobhan Murray. 2009. "Improving Connectivity: Investing in Transport Infrastructure in Sub-Saharan Africa." AICD Background Paper 7, Africa Region, World Bank, Washington, DC.

Gwilliam, Ken, Vivien Foster, Rodrigo Archondo-Callao, Cecilia Briceño-Garmendia, Alberto Nogales, and Kavita Sethi. 2008. "The Burden of Maintenance: Roads in Sub-Saharan Africa." AICD Background Paper 14, Africa Region, World Bank, Washington, DC.

Heinrich C. Bofinger. 2009. “An Unsteady Course: Growth and Challenges in Africa's Air Transport Industry.” AICD Background Paper 16, Africa Region, World Bank, Washington, DC.

Kumar, Ajay, and Fanny Barrett. 2008. "Stuck in Traffic: Urban Transport in Africa." AICD Background Paper 1, Africa Region, World Bank, Washington, DC.

Ocean Shipping Consultants, Ltd. 2009. "Beyond the Bottlenecks: Ports in Africa." AICD Background Paper 8, Africa Region, World Bank, Washington, DC.

\section{Water supply and sanitation}

Banerjee, Sudeshna, Vivien Foster, Yvonne Ying, Heather Skilling, and Quentin Wodon. 2008. "Cost Recovery, Equity, and Efficiency in Water Tariffs: Evidence from African Utilities.” AICD Working Paper 7, World Bank, Washington, DC.

Banerjee, Sudeshna, Heather Skilling, Vivien Foster, Cecilia Briceño-Garmendia, Elvira Morella, and Tarik Chfadi. 2008. "Ebbing Water, Surging Deficits: Urban Water Supply in Sub-Saharan Africa.” AICD Background Paper 12, Africa Region, World Bank, Washington, DC.

Gulyani, Sumila, Debabrata Talukdar, and Darby Jack. 2009. "Poverty, Living Conditions, and Infrastructure Access: A Comparison of Slums in Dakar, Johannesburg, and Nairobi.” AICD Working Paper 10, World Bank, Washington, DC.

Keener, Sarah, Manuel Luengo, and Sudeshna Banerjee. 2009. "Provision of Water to the Poor in Africa: Experience with Water Standposts and the Informal Water Sector.” AICD Working Paper 13, World Bank, Washington, DC.

Morella, Elvira, Vivien Foster, and Sudeshna Ghosh Banerjee. 2008. "Climbing the Ladder: The State of Sanitation in Sub-Saharan Africa." AICD Background Paper 13, Africa Region, World Bank, Washington, DC. 